ISSN: 2146-3042

DOI: $10.25095 /$ mufad.852083

\title{
Muhasebe Eğitimi İle İlgili Lisansüstü Tezlerin Analizi (1991-2019)*
}

\author{
Hakan CAVLAK** \\ Yasin CEBECI'*** \\ Necati GÜNEŞ**** \\ Ömer Faruk TAN ${ }^{* * * * *}$
}

\section{ÖZET}

Muhasebe eğitimi, yükseköğretim öncesi kurumlar için önem arz ettiği gibi yükseköğretim kurumları için de son derece önemli bir role sahiptir. Bu önemli rolün en önemli çıktısı, muhasebe mesleğini en iyi şekilde gerçekleştiren kişiler vasıtasıyla işletmelerin daha şeffaf, adil ve hesap verebilir olmasının sağlanmasıdır. Bu da doğrudan hem işletme hem de ülke performansını etkilemektedir. Bu açıdan bakıldı̆̆ında üniversitelerde muhasebe eğitimi ile ilgili gerçekleştirilen çalışmalar büyük önem arz etmektedir. Türkiye'de ilk olarak 1991 yılında ODTÜ'de hazırlanan bir yüksek lisans tezi ile lisansüstü çalışmalara konu olan muhasebe eğitimi, çeşitli açılardan o yıldan günümüze kadar muhtelif yüksek lisans ve doktora çalışmalarında incelenmektedir. Bu çalışmada da taşıdığı önem dolayısıyla muhasebe eğitimi ile ilgili yazılmış olan ve YÖK Ulusal Tez Merkezi'nde listelenen 98 tez içerik analizi yöntemi ile analiz edilmiştir. Tezlerin genel özellikleri, yıllara göre dağılımı, üniversite, bölge, enstitü, vb. özellikleri, dizin ve anahtar kelimeleri ile araştırmaların kaynakları ve yöntemlerine dair bulgular ortaya konulmuştur. Son olarak ise bulgulardan hareketle muhasebe eğitimi ile ilgili genel değerlendirmelerde ve gelecekte konu ile ilgili yapılacak çalışmalar için önerilerde bulunulmuştur.

Anahtar Kelimeler: Muhasebe Eğitimi, Lisansüstü Tez, İçerik Analizi.

JEL Sinıflandirması: I23, M41.

\section{Analysis of Graduate Theses About Accounting Education (1991-2019)}

\section{ABSTRACT}

Accounting education is not only important for pre-higher education institutions but also has an extremely important role for higher education institutions. The most important output of this important role is to ensure that businesses are more transparent, fair and accountable through the people who perform the accounting profession in the best way. This directly affects both business and country performance. From this point of view, studies on accounting education at universities are of great importance. Accounting education has become subject of graduate studies in Turkey with first prepared a master's thesis at METU in 1991. It is examined in various postgraduate and doctoral studies from various perspectives that year until today. In this study, due to the importance it carries, 98 theses written about accounting education and listed in YÖK National Thesis Center were analyzed by content analysis method. Findings about general characteristics of theses, distribution by years, university, region, institute, other properties, indexes and keywords and the sources and methods of the researches are presented. Finally, based on the findings, general evaluations about accounting education and suggestions for future studies on the subject were made.

Keywords: Accounting Education, Graduate Thesis, Content Analysis.

Jel Classification: I23, M41.

* Makale Gönderim Tarihi: 03.03.2020, Makale Kabul Tarihi: 20.03.2020, Makale Türü: Nitel Araştırma

** Arş. Gör. Dr., Ardahan Üniversitesi, İİBF, hakancavlak@ardahan.edu.tr, ORCID: 0000-0002-5891-7722.

*** Arş. Gör. Dr., Marmara Üniversitesi, İşletme Fakültesi, yasin.cebeci@marmara.edu.tr, ORCID: 0000-00020110-8625.

**** Arş. Gör., Marmara Üniversitesi, İşletme Fakültesi, necati.gunes@marmara.edu.tr, ORCID: 0000-00022390-4868.

***** Arş. Gör., Marmara Üniversitesi, İşletme Fakültesi, omer.tan@marmara.edu.tr, ORCID ID: 0000-00028875-4696. 


\section{GíRiş}

İşletmelere ilişkin para ile ifade edilebilen ekonomik verilerin ölçüm, kayıt ve iletişim aracı olan muhasebe, sadece işletmeler için önem arz etmemekte aynı zamanda içinde bulunduğu toplum ve ülkeler adına da önemli bir sorumluluk taşımaktadır (Hindmarch, Atchison ve Marke, 1977: 3). Taşıdığı sorumluluk ve arz ettiği önem çerçevesinde işletme faaliyetleri ve sonuçları ile ilgili şeffaf, doğru ve güvenilir bilgilerin tüm paydaşlara sunulabilmesi muhasebe alanında çalışacak kişilerin iyi bir muhasebe eğitimi almış olmasına bağlıdır. Bu doğrultuda ülke ekonomilerinin gereksinim duyduğu muhasebe elemanlarının eğitimi özel bir önem taşımaktadır. Söz konusu muhasebe eğitiminin de bu duruma istinaden ekonominin her düzeyde gereksinim duyduğu muhasebe elemanını yetiştirecek seviyede olması gerekmektedir (Şengel, 1998: 247).

Muhasebenin kendinden beklenen sorumlulukları yüksek seviyede yerine getirmesinde en önemli araç, uygulayıcılara yükseköğretimde verilen muhasebe eğitimidir. Muhasebe ve buna bağlı olarak muhasebe eğitimi, verilmeye başladığından bu yana sürekli bir değişim halindedir. Söz konusu değişim; iş yapma şeklindeki değişikliklere, teknolojik gelişmelere, muhasebe çıktıları olan finansal tablolardan beklentilere ve muhasebe standartlarının değişimine bağlı olarak şekil almıştır (Belverd E. Needles, 2014: 27).

Muhasebe eğitiminin temel hedefi, eğitimi alan kişilere muhasebe ile ilişkili ve ilgili olan gerekli yetkinlikleri kazandırmaktır. $\mathrm{Bu}$ yönüyle de muhasebe eğitiminin kalitesi, muhasebe mezunlarının değişen koşullar karşısında muhasebe bilgisi paydaşlarının taleplerini karşılama derecelerine bağlıdır. Dolayısıyla muhasebe eğitiminde ortaya çıkan değişiklik ihtiyacı özellikle son yıllarda artan bir sıklıkla dile getirilmektedir (Yaşar, 2019: 96).

İfade edildiği gibi muhasebe eğitiminin kalitesinde yükseköğretim önemli bir yere sahip olmakla birlikte; muhasebe eğitimcilerinin de yaşanan ve yaşanabilecek değişimler karşısında yükseköğretimdeki değişim isteklerini ve muhasebe eğitim programlarının mevcut durumunu iyi bir şekilde anlamaları ve analiz etmeleri gerekmektedir (Pincus, Stout, Sorensen, Stocks ve Lawson, 2017: 1). Bu analiz ile birlikte önemli bir çıktı olarak lisansüstü eğitim sonucunda oluşturulacak olan tezlerde muhasebe eğitiminin geleceğine dair konuların danışmanlar aracılığı ile işlenebilmesi ve uygulamaya yönelik çözümlerin üretilebilmesi sağlanabilecektir. Bu üretim ise Türkiye'deki muhasebe eğitimi ve uygulamalarını etkileyen olayların tarihçesini gösteren Türkiye Muhasebe Eğitimi Sempozyumları (Gücenme, 2006, s. 40) gibi muhasebe eğitiminin önemli bir tarafını oluşturan yükseköğretimdeki kaliteyi arttıracaktır.

Bu çalışmada, muhasebe eğitiminin önemli bir parçası ve çıktısı olan lisansüstü tezler ele alınmaktadır. Öncelikle muhasebe eğitimine dair bazı temel noktalara değinilmekte daha sonra ise muhasebe eğitimi ile ilgili Türkiye'de yazılmış olan lisansüstü tezler, içerik analizi yöntemi ile incelenmektedir. Son olarak ise analiz sonuçları değerlendirilmekte ve gelecekte muhasebe eğitimi ile ilgili yazılacak lisansüstü tezlere dair önerilerde bulunulmaktadır.

\section{MUHASEBE EĞİTiMi}

Ülkelerin vizyonlarını belirlemede muhasebe ve muhasebe eğitimi stratejik bir öneme sahiptir. Ekonomik ve toplumsal olarak önemli bir işleve sahip olan muhasebe; ülkelerin 
ekonomik değerlerini ve dolayısıyla kurumsallık, şeffaflık, hesap verebilirlik, adillik ve sorumluluk gibi unsurlarının gerçekleştirilmesini sağlayan temel dinamiklerden birisidir (Güney, 2019: 941).

1986 y1lında yayınlanan Bedford Raporu'nda yer alan; “...Kapsamlı bir eğitimin temeli, muhasebecinin yüksek ögreniminden elde edilir... Bu türde ĕgitim vermeye, ideal bakımdan engin akademik kadrolarlyla üniversiteler uygundur." ve “...Üniversitede muhasebe ĕgitimi yaşam boyu öğrenme için gerekli kabiliyet ve becerileri güçlendirmelidir...Üniversiteler, muhasebe eğitiminde toplumun bilgi ihtiyaçlarındaki değişimlere huzla ayak uydurabilmeye izin verecek şekilde esneklik idame ettirmelidirler." (Kaya, 1999: 73) ifadeleri muhasebe eğitiminde üniversitelerin, akademik kadroların ve dolayısıyla bu kurum ve kişiler vasıtasıyla ortaya çıkan çalışmaların önemini göstermektedir.

Yıllar içerisinde muhtelif nedenler ile değişim gösteren muhasebe eğitimi, dünyadaki ülkelerin çoğunda mesleki ve teknik liselerde verilmekle birlikte ağırlıklı olarak üniversitelerde sürdürülmektedir (Mueller, 1994: 8). Türkiye'de yaşanan durum ise dünyada yaşanan durum ile benzerlik göstermektedir. Türkiye'de muhasebe eğitimi uzun yıllardır ortaöğretim düzeyinden başlayarak lisansüstü düzeye kadar devam edecek şekilde yürütülmektedir. 1990'lı yıllarda; üniversitelerin Türkiye'de yaygınlaşması, öğretim kadrolarının zenginleşmesi, muhasebe uygulama mesleğinin örgütlenmesi, muhasebe sistemi ve tekdüzen hesap planının yürürlüğe girmesi ve benzeri gelişmeler Türkiye'deki muhasebe yapısına ve buna bağlı olarak muhasebe eğitimine yön vermiştir. Bu çerçevede, muhasebe uygulamaları da eğitim ve öğretim boyutu ile birçok bilimsel çalışma ve toplantılarda ele alınan önemli bir konu haline gelmiştir (Altınay, 2016: 2147; Güvemli, 2009: 230).

Türkiye'de ilk muhasebe eğitimine, 1859 yılında kurulan ve o zamanki adı Mekteb-i Mülkiye-i Şahane olan Ankara Üniversitesi Siyasal Bilgiler Fakültesi’nde başlanmıştır. Daha sonra 1883'te Hamidiye Ticaret Mektebi ismi ile kurulan Marmara Üniversitesi İşletme Fakültesi muhasebe alanında en kapsamlı eğitimi vermeye başlamıştır. 1914 yılında ise Siyasal Bilgiler Fakültesi kurulmuş ve muhasebe eğitimi verilmiştir. Daha sonraki yıllarda da muhasebe eğitimi alanında Türkiye'de hızlı bir okullaşma başlamış olup yüksek dereceli okullar, meslek yüksekokulları ve orta öğretim kurumlarının bazılarında muhasebe eğitimi çağın gereklilikleri doğrultusunda en üst düzeyde verilmeye başlanmıştır (Özdoğan, 1978).

Türkiye'de muhasebe eğitimi alanında yaşanan pozitif gelişmeler ile birlikte koordinasyon eksikliği nedeniyle uluslararası gelişmelerden haberdar olunamaması, eğitim veren kuruluşlardan sürekli bilgi gelmemesi, personel sayısının azlığı, konuya gereken önemin verilmemesi, kaynak ve zaman ayrılmaması gibi gelişmeler muhasebe eğitimindeki pozitif ivmenin dönem dönem yavaşlamasına neden olmuştur (Korukoğlu, 1998: 20).

Muhasebe eğitimi dünyada olduğu gibi Türkiye'de de lisans, yüksek lisans ve doktora düzeyinde birçok üniversitede verilmektedir. Alınan muhasebe eğitimi hem iş dünyası açısından hem de akademik açıdan önemli bir bilgi birikimi sunmaktadır (Çelenk, Atmaca ve Horasan, 2010: 159). Söz konusu bilgi birikiminin en büyük kaynağı ise konu hakkında yazılan makalelerde ve tezlerde ortaya konan görüşlerdir. Bir başka ifade ile muhasebe eğitiminin etkinliğini arttırmanın önemli yöntemlerinden biri muhasebeye ilişkin araştırmaların ve yayınların arttırılmasıdır (Tekşen, Tekin ve Gençtürk, 2010: 111). 
Yükseköğretimde verilen muhasebe eğitiminin, geçmişe nazaran her gün yeni bir gelişmenin yaşandığı mevcut ekonomik ortamda hayatta kalabilmek için içeriğinde değişiklikler yapılmalıdır (Burnett, 2003: 133). Son yıllarda etkisini daha da arttıran teknolojik gelişmeler, kuşak farkı, eğitim anlayışının değişimi gibi bazı etmenler her eğitim unsurunu etkilediği gibi muhasebe eğitimini de etkilemektedir. Bu etkinin giderilmesi için ise muhasebe eğitimi alanında; ders programlarının gözden geçirilmesi, öğretim materyallerinin güncellenmesi ve öğretim elemanlarının donanımlarının yeterli seviyeye çıkarılması gerekmektedir (Türegün ve Kaya, 2019: 340). Bununla birlikte yeterli tecrübe ve donanıma sahip danışmanların lisansüstü öğrencileri doğru bir şekilde yönlendirerek uygulamaya yönelik muhasebe eğitimi ile ilgili ve ilişkili konularda çalışmalar yapması da bir zorunluluk olarak ifade edilebilmektedir.

\section{LITERATÜR TARAMASI}

Muhasebe alanında muhtelif konularda birçok başlık çerçevesinde lisansüstü çalışmalar yapılmıştır ve yapılmaya da devam etmektedir. Söz konusu çalışmalar olan yüksek lisans ve doktora tezlerinin yıllar içinde nasıl bir seyir izlediği ve muhasebenin hangi alanlarında dağılım gösterdiği de çeşitli akademik çalışmalarda içerik ve bibliyometrik analiz yöntemleri ile incelenmiştir. Her ne kadar özel olarak muhasebe eğitimi konusunda yazılan tezlerin bugüne kadar analizi yapılmasa da muhasebe ya da muhasebenin alt alanlarında yazılan tezlerin genel değerlendirilmesi çeşitli akademik çalışmalara konu olmuştur. Tablo 1'de bu alanlarda yapılan lisansüstü çalışmalara ilişkin literatür çalışması yer almaktadır. Literatür çalışmasında konu ile ilgili 2010 öncesi yapılan çalışmalara sempozyumlarda sunulmasından dolayı ulaşılamadığından sonraki yıllardaki çalışmalar dikkate alınmış olup bu çalışmaların muhasebe eğitimi ile ilgili bulgularına yer verilmiştir.

Tablo 1. Muhasebe Alanında Lisansüstü Tezler ile İlgili Yapılan Çalışmalar

\begin{tabular}{|l|l|}
\hline Yazar(lar) ve Yıl & Çalışma Hakkında \\
\hline (Alkan, 2014) & $\begin{array}{l}\text { Çalışmada, 1984-2012 yılları arasında muhasebe alanında yazılan ve YÖK Ulusal Tez } \\
\text { Merkezi’nde erişime açı } 656 \text { lisansüstü tez içerik analizi yöntemi ile incelenmiştir. } \\
\text { Muhasebe eğitimi ile ilgili temel bulgu, incelenen yıllar kapsamında muhasebe alanında } \\
\text { yazılan tezlerin \%4'ünün muhasebe eğitimi ile ilgili olmasıdır. }\end{array}$ \\
\hline $\begin{array}{l}\text { (Yücel, Öncü ve } \\
\text { Kartal, 2015) }\end{array}$ & $\begin{array}{l}\text { Çalışmanın bir bölümünde, 2007-2014 yılları arasında uluslararası muhasebe ve finansal } \\
\text { raporlama standartları ile ilişkili alanları ifade eden birçok anahtar kelime yardımı } \\
\text { kapsamında YÖK Ulusal Tez Merkezi'nde erişime açı 364 lisansüstü tez incelenmiştir. } \\
\text { Çalışmada, araştırma bulguları çerçevesinde ulaşılan sonuçlardan hareketle muhasebe } \\
\text { eğitimi ile ilgili veya ilişkili herhangi bir tespit yapılmamıştır. }\end{array}$ \\
\hline (Güngörmüş, 2016) & $\begin{array}{l}\text { Çalışmada; Uluslararası Muhasebe Standartları, Türkiye Muhasebe Standartları, } \\
\text { Uluslararası Finansal Raporlama Standartları, Türkiye Finansal Muhasebe Standartları, } \\
\text { UMS, TMS, UFRS, TFRS, IAS anahtar kelimeleri geçen ve YÖK Ulusal Tez Merkezi’nde } \\
\text { yer alan 312 lisansüstü tez içerik analizi ile incelenmiştir. Çalışmada, araştırma bulguları } \\
\text { çerçevesinde ulaşılan sonuçlardan hareketle muhasebe eğitimi ile ilgili veya ilişkili } \\
\text { herhangi bir tespit yapılmamıştır. }\end{array}$ \\
\hline $\begin{array}{l}\text { Çalışmada, adli muhasebe alanında yazılan ve YÖK Ulusal Tez Merkezi’nde yer alan 24 } \\
\text { lisansüstü tez incelenmiştir. Çalışmada, araştırma bulguları çerçevesinde ulaş1lan } \\
\text { sonuçlardan hareketle muhasebe eğitimi ile ilgili veya ilişkili herhangi bir tespit } \\
\text { yapılmamış olup özel olarak adli muhasebe eğitimi ile ilgili tespitlerde bulunulmuştur. }\end{array}$ \\
\hline
\end{tabular}




\begin{tabular}{|c|c|}
\hline $\begin{array}{l}\text { (Durgut ve Pehlivan, } \\
\text { 2018) }\end{array}$ & $\begin{array}{l}\text { Çalışmada, 1987-2017 yılları arasında muhasebe ve finansal raporlama standartları } \\
\text { konusunda yazılan ve YÖK Ulusal Tez Merkezi’nde erişime açı olan ve olmayan } 222 \\
\text { lisansüstü tez içerik analizi yöntemi ile incelenmiştir. Çalışmada, araştırma bulguları } \\
\text { çerçevesinde ulaşılan sonuçlardan hareketle muhasebe eğitimi ile ilgili veya ilişkili } \\
\text { herhangi bir tespit yapılmamıştır. }\end{array}$ \\
\hline $\begin{array}{l}\text { (Yeşil ve Akyüz, } \\
\text { 2018) }\end{array}$ & $\begin{array}{l}\text { Çalışmada, 25.05.2018 tarihinde YÖK Ulusal Tez Merkezi’nde muhasebe kelimesi izinli } \\
320 \text { doktora tezi bibliyometrik analiz yöntemi ile incelenmiştir. Çalışmada muhasebe } \\
\text { eğitimi ile ilgili temel bulgu, incelenen } 320 \text { doktora tezinden sadece 5’inin muhasebe } \\
\text { eğitimi konusunda yapılmış olmasıdır. }\end{array}$ \\
\hline (Uyar, 2018) & $\begin{array}{l}\text { Çalışmada, muhasebe hata ve hileleri konusunda yazılan ve erişime açık } 47 \text { lisansüstü tez } \\
\text { incelenmiştir. Çalışmada, araştırma bulguları çerçevesinde ulaşılan sonuçlardan hareketle } \\
\text { muhasebe eğitimi ile ilgili veya ilişkili herhangi bir tespit yapılmamıştır. }\end{array}$ \\
\hline $\begin{array}{l}\text { (Çoban Çelikdemir, } \\
\text { 2019) }\end{array}$ & $\begin{array}{l}\text { Çalışmada, 1991-2018 yılları arasında muhasebe standartları konusunda yazılan ve YÖK } \\
\text { Ulusal Tez Merkezi'nde erişime açı } 555 \text { lisansüstü tez içerik analizi yöntemi ile } \\
\text { incelenmiştir. Çalışmada, araştırma bulguları çerçevesinde ulaşılan sonuçlardan hareketle } \\
\text { muhasebe eğitimi ile ilgili veya ilişkili herhangi bir tespit yapılmamıştır. }\end{array}$ \\
\hline $\begin{array}{l}\text { (Güleç ve Öztürk, } \\
\text { 2019) }\end{array}$ & $\begin{array}{l}\text { Çalışmada; muhasebe, muhasebe-finansman, muhasebe denetim bilim dallarında yazılan } \\
\text { ve YÖK Ulusal Tez Merkezi'nde yer alan } 613 \text { lisansüstü tez içerik analizi ile incelenmiştir. } \\
\text { Çalışmada muhasebe eğitimi ile ilgili temel bulgu, muhasebe alanında yazılan tezlerde yer } \\
\text { alan toplam } 1.120 \text { anahtar kelimeden 3'ünün muhasebe eğitimi ifadesine yer vermesidir. }\end{array}$ \\
\hline (H. P. Kaya, 2019) & $\begin{array}{l}\text { Çalışmada, 1995-2018 yılları arasında muhasebe bilim dalının denetim alanı ile ilgili } \\
\text { yazılan ve YÖK Ulusal Tez Merkezi'nde erişime açı } 128 \text { doktora tezi incelenmiştir. } \\
\text { Çalışmada, araştırma bulguları çerçevesinde ulaşılan sonuçlardan hareketle muhasebe } \\
\text { eğitimi ile ilgili veya ilişkili herhangi bir tespit yapılmamıştır. }\end{array}$ \\
\hline $\begin{array}{l}\text { (Şahin ve } \\
\text { Karaaslanoğlu, 2019) }\end{array}$ & $\begin{array}{l}\text { Çalışmada, 2013-2018 yılları arasında muhasebe alanında yazılan ve YÖK Ulusal Tez } \\
\text { Merkezi'nde erişime açık } 623 \text { lisansüstü tez içerik analizi yöntemi ile incelenmiştir. } \\
\text { Muhasebe eğitimi ile ilgili temel bulgu, incelenen yıllar kapsamında muhasebe alanında } \\
\text { yazılan tezlerin \%2,9'unun (20 tanesinin) muhasebe eğitimi ile ilgili olmasıdır. }\end{array}$ \\
\hline
\end{tabular}

Tablo 1'den de görüleceği üzere literatürde muhasebe eğitimi özelinde yapılmış olan lisansüstü tezler değerlendirmeye tabi tutulmamış, ağırlıklı olarak muhasebe ve muhasebenin alt alanlarında yapılan lisansüstü çalışmalar incelenmiştir. Bu tablonun bir sonucu olarak bu çalışmada, literatürde eksik olan bir konu olarak ifade edilebilecek muhasebe eğitimi konusunda Türkiye' de yazılmış lisansüstü tezler araştırma konusu olarak seçilmiştir.

\section{MUHASEBE EĞITTIMI İLE İLGILİ LISSANSÜSTÜ TEZLER ÜZERINE BİR ARAŞTIRMA}

\subsection{Araştırmanın Amacı, Kapsamı ve Yöntemi}

Araştırmanın temel amacı, literatür çalışmasında bir boşluk olarak tespit edilen muhasebe eğitimi ile ilgili Türkiye'deki üniversitelerde yazılmış olan lisansüstü tezleri içerik, kapsam, araştırma konusu gibi hususlar bakımında araştırmak ve ortaya çıkan bulguları muhtelif yönlerden sınıflandırarak değerlendirmelerde bulunmaktır. Çalışmanın bir diğer amacı ise muhasebe eğitimi konusunda yazılan lisansüstü tezlerin zaman içindeki seyrini çeşitli açılardan ele alarak ileriye yönelik çıkarımlar yapmaktır.

Araştırmanın kapsamını, YÖK Ulusal Tez Merkezi'nde kayıtlı bulunan ve muhasebe eğitimi ile ilgili olan yüksek lisans ve doktora tezleri oluşturmaktadır. Bu çerçevede, 
23.01.2020 tarihi itibariyle tez.yok.gov.tr adresinde yer alan gelişmiş tarama sekmesinde aranacak kelimeler kısmına "muhasebe eğitimi" ifadesi girilmiş, aranacak alan olarak tümü, arama tipi olarak ise sadece yazılan şekilde seçeneği işaretlenmiştir. Tarama sonucunda 98 adet kayit listelenmiştir. Muhasebe eğitimi ile ilgili listelenen tezlere ait bilgiler erişimin izin verildiği ölçüde ya tez bilgileri detay kısmından ya da indirme kısmındaki dosyadan toplanarak analize hazır hale getirilmiştir.

Araştırmanın yöntemi olarak toplanan veriler içerik analizine tabi tutulmuştur. İçerik analizini; metinlerden ve diğer iletişim biçimlerinden sistematik, geçerli, güvenilir ve tekrarlanabilir çıkarımlar yapmak için kullanılan bir araştırma tekniği olarak ifade etmek mümkündür (Drisko ve Maschi, 2016: 7). İçerik analizinde yapılan temel işlem, birbirine benzeyen verilerin belirlenmiş kavramlar kapsamında bir araya getirilmesi ve bunların anlaşılabilir biçimde düzenlenerek yorumlanmasıdır (Şimşek ve Yıldırım, 2016: 259). Araştırma kapsamında uygulanacak içerik analizi, tezlere ait verilerin Microsoft Excel programına girilmesi ve kategorilendirilmesi ile gerçekleştirilmiştir.

\subsection{Araştırmanın Varsayımları ve Kısıtları}

Araştırma kapsamındaki muhasebe eğitimi ile ilgili tezlere ait varsayımlar şunlardır:

$\checkmark$ Veri tabanında kayıtlı olan tezlerin muhasebe eğitimi ile ilgili tüm tezleri içerdiği,

$\checkmark \quad$ Tezlere ait bilgilerin eksiksiz ve doğru olarak sisteme kaydedildiği.

Araştırmanın kısıtlarını ise aşağıdaki unsurlar oluşturmaktadır:

$\checkmark$ Araştırmanın kapsamını akademik çalışmalar arasından sadece lisansüstü tezler oluşturmaktadır. Makale, bildiri ve diğer akademik çalışmalar kapsam dışı bırakılmış̧ır. Bunun nedeni muhasebe eğitimi ile ilgili alanda sadece lisansüstü tezlere yönelik boşluğun bulunmasıdır. Konu ile ilgili makale, bildiri ve diğer konularda yapılan çalışmalar mevcuttur.

$\checkmark$ Araştırmanın kısıtlarından biri de veri tabanında aranacak alan kısmında (tümü seçeneği işaretlenmiş olup bu seçenek teze ait tez adl, yazar, danışman, konu, dizin ve özet unsurların içermektedir) sadece muhasebe eğitimi kelimesi yer alan ve sisteme 23.01.2020 tarihine kadar kaydedilmiş çalışmaların ele alınmasıdır.

$\checkmark$ Araştırmada bir diğer kısıt, kullanılan içerik analizi ile muhasebe eğitimi kavramı altında incelen alt başlıkların, ilgili tezlerde kullanılan anahtar kelimeler ve dizin ifadeleri çerçevesinde ele alınmasıdır. Ayrıca, yazarlar tarafindan belirtilen söz konusu kelime ve ifadelerin, muhasebe eğitimi ile ilgili ele alınan konuları temsil ettiği varsayılmışır.

Tezlerin; erişime açık olmaması veya TÜBESS (Türkiye Belge Sağlama Sistemi) üzerinden ulaşılabilmesi araştırmanın kısııını oluşturmamaktadır. Bu tezlere ait veriler YÖK Ulusal Tez Merkezinde yer alan tez bilgileri detay kısmından alınarak analize dahil edilmiştir.

\subsection{Araştırmanın Bulguları}

Muhasebe eğitimi ile ilgili YÖK Ulusal Tez Merkezi'nde kayıtlı bulunan 98 adet lisansüstü teze ait verilerin içerik analizi yöntemi ile incelenmesi sonucunda ortaya çıkan 
bulgular, beş alt başlık içerisinde değerlendirilmiştir. Bunlar; tezlerin genel özellikleri itibariyle, y1llara göre, üniversitelerin özelliklerine göre, tezlere ait dizin ve anahtar kelimelere göre, tezlerin araştırma yöntemleri açısından değerlendirilmesi olarak ifade edilebilir. Bulguların bir bütün olarak değerlendirilmesi ve bulgulardan hareketle gelecek dönemlere ilişkin yapılabilecek çıkarımlar, çalışmanın sonuç ve öneriler kısmında yer almaktadır.

\subsubsection{Tezlerin Genel Özellikleri}

Muhasebe eğitimi ile ilgili tezlerin genel özelliklerine ait ilk unsur, YÖK Ulusal Tez Merkezi'nde yapılan arama sonucunda listelenen tezlerin erişilebilirliğine yöneliktir. Söz konusu duruma ait görünüm, Tablo 2'de sunulmaktadır.

Tablo 2. Muhasebe Eğitimi ile İlgili Lisansüstü Tezler:

\begin{tabular}{|l|c|}
\multicolumn{2}{|c}{ Erişilebilirlik } \\
\hline Erişilebilirlik & Frekans (\%) \\
\hline Erişilebilir & $81(\% 82,65)$ \\
\hline TÜBESS Üzerinden Erişilebilir & $13(\% 13,27)$ \\
\hline Yazar Tarafindan Kisıtlı & $4(\% 04,08)$ \\
\hline Toplam & $\mathbf{9 8}(\% 100)$ \\
\hline
\end{tabular}

Tablo 2'de de görüldügüü üzere 98 tezden 81 'ine direkt erişim mümkünken 13 teze de TÜBESS üzerinden erişim sağlanabilmektedir. 4 tez ise kısıtlandığ sonra erişim sağlanacaktır. Yazar tarafından kısıtlı olan 2017 yılında ait 4 lisansüstü tezin; 3'ü yüksek lisans, 1'i ise doktora çalışmasıdır. TÜBESS üzerinden erişilebilir tezlerin yıl aralığı, 1991 ile 2004 yılları arasındadır. Erişilebilir tezlere ait ilk tez ise 2001 yılına aittir.

Tezlerin genel özellikleri itibari ile değerlendirilmesinde ikinci unsur ise tezlerin tür olarak nasıl bir dağılım gösterdiğine ilişkindir. Söz konusu dağılım, Tablo 3’teki gibidir.

Tablo 3. Muhasebe Eğitimi ile İlgili Lisansüstü Tezler: Tez Türü

\begin{tabular}{|l|c|c|c|c|c|}
\hline \multirow{2}{*}{ Tez Türü } & \multirow{2}{*}{ Frekans (\%) } & \multirow{2}{*}{$\begin{array}{c}\text { Ortalama } \\
\text { Sayfa Sayısı }\end{array}$} & \multicolumn{3}{|c|}{ Danışman Unvanı } \\
\cline { 5 - 6 } & & & Prof. Dr. & Doç. Dr. & $\begin{array}{c}\text { Dr. Öğr. } \\
\text { Üyesi }\end{array}$ \\
\hline Yüksek Lisans (YL) & $86(\% 87,76)$ & 138 sayfa & 23 & 28 & 34 \\
\hline Doktora (DR) & $12(\% 12,24)$ & 231 sayfa & 10 & 2 & 0 \\
\hline Toplam & $\mathbf{9 8}(\% 100)$ & $\mathbf{1 5 0}$ sayfa & 33 & 30 & 34 \\
\hline
\end{tabular}

Muhasebe eğitimi ile ilgili 98 tezden 86'sı yüksek lisans, 12'si ise doktora tezi olarak gözükmektedir. Yazılan yüksek lisans tezlerinin ortalama sayfa sayısı 138 iken doktora tezlerinin ortalama sayfa sayısı ise 231 sayfadır. Toplam 98 lisansüstü tezin ortalama sayfa sayısı ise 150 sayfadır. Yüksek lisans tezlerinin danışmanlarına ait unvanlar; 23 Prof. Dr., 28 Doç. Dr., 34 Dr. Öğr. Üyesi şeklinde, doktora tezlerinin danışmanlarına ait unvanlar; 10 Prof. Dr., 2 Doç. Dr. şeklindedir. Bir yüksek lisans tezinde danışman bilgisi yer almamaktadır. 
Tezlere ait genel özelliklerden biri de tezlerin dilidir. Söz konusu unsura ait bilgiler, Tablo 4'te gösterilmektedir. Tezler, Türkçe ve İngilizce olmak üzere iki ayrı dilde yazılmıştır.

Tablo 4. Muhasebe Eğitimi ile İlgili Lisansüstü Tezler:

\begin{tabular}{|l|c|c|c|}
\hline \multicolumn{4}{|c}{ Tez Dili } \\
\hline \multirow{2}{*}{ Tez Dili } & \multicolumn{2}{|c|}{ Frekans (\%) } & $\begin{array}{c}\text { Ortalama } \\
\text { Sayfa Sayısı }\end{array}$ \\
\hline \multirow{2}{*}{$\begin{array}{l}\text { Türkçe } \\
\text { (TR) }\end{array}$} & \multicolumn{2}{|c|}{$95(\% 96,94)$} & \multirow{2}{*}{148 sayfa } \\
\cline { 2 - 3 } & 84 YL & $11 \mathrm{DR}$ & \\
\hline \multirow{2}{*}{$\begin{array}{l}\text { İngilizce } \\
\text { (ING) }\end{array}$} & \multicolumn{2}{|c|}{$3(\% 03,06)$} & \multirow{2}{*}{213 sayfa } \\
\cline { 2 - 3 } Toplam & 2 YL & 1 DR & \\
\hline \multirow{2}{*}{ To (\%100) } & 150 sayfa \\
\hline
\end{tabular}

Tablo 4’te de görüldüğü gibi muhasebe eğitimi ile ilgili yazılan 98 lisansüstü tezin; 95'i Türkçe, 3’ü ise İngilizce olarak yazılmıştır. Türkçe yazılan 95 tezin; 84'ü yüksek lisans, $11^{\prime} \mathrm{i}$ ise doktora tezi olmak üzere bu tezlerin ortalama sayfa sayısı ise 148 sayfadır. İngilizce yazılan 3 tezin; 2'si yüksek lisans, 1'i ise doktora tezi olmak üzere söz konusu tezlerin ortalama sayfa sayısı 213 sayfadır. Diğer taraftan Türkçe yazılan tezlerdeki danışmanların unvanları; Prof. Dr., Doç. Dr., Dr. Öğr. Üyesi arasında dengeli olarak dağılırken İngilizce tezler unvanı sadece Prof. Dr. olan danışmanlar tarafından yazdırılmıştır. Türkçe yazılan bir yüksek lisans tezinde danışman bilgisi yer almamaktadır.

Muhasebe eğitimi ile ilgili yazılan İngilizce lisansüstü tezlerden 2'si yüksek lisans tezi (2'si de ODTÜ'de 1991 ve 1995 yillarında Sosyal Bilimler Enstitüsü'nde), 1'i ise doktora tezi (Boğaziçi Üniversitesi’nde 2008 yllında Sosyal Bilimler Enstitüsü Yönetim Bilimleri Anabilim Dalı'nda) olarak yazılmıştır.

Muhasebe eğitimi ile ilgili yazılan lisansüstü tezlerin hangi unvana sahip danışmanlar ile birlikte yazıldığı incelendiğinde Tablo 5'teki görünüm ortaya çıkmaktadır. Bir yüksek lisans tezine ait danışman bilgisine ulaşılamadığından 97 tez üzerinden dağılım yapılmıştır.

Tablo 5. Muhasebe Eğitimi ile İlgili Lisansüstü Tezler:

Danışman Unvanı

\begin{tabular}{|l|c|c|c|}
\hline \multirow{2}{*}{ Danışman Unvanı } & \multicolumn{3}{|c|}{ Frekans (\%) } \\
\cline { 2 - 4 } Prof. Dr. & YL & DR & Toplam \\
\hline Doç. Dr. & 23 & 10 & $\begin{array}{c}33 \\
(\% 34,02)\end{array}$ \\
\hline Dr. Öğr. Üyesi & 28 & 2 & $\begin{array}{c}30 \\
(\% 30,93)\end{array}$ \\
\hline Toplam & 34 & 0 & $\begin{array}{c}34 \\
(\% 35,05)\end{array}$ \\
\hline
\end{tabular}

Tablo 5'te görüldüğü üzere; 1997 yılında yazılan bir yüksek lisans tezine ait danışman bilgisinin girilmemesinden dolayı 97 tez üzerinden analiz edilen danışman unvanı bilgilerine göre; 33 tez Prof. Dr., 30 tez Doç. Dr., 34 tez ise Dr. Öğr. Üyesi danışmanlığında yazılmıştır. 
Unvanlar arasında yakın bir dağılım olduğu görülmektedir. Doktora tezleri ise ağırlıklı olarak Prof. Dr., yüksek lisans tezleri ise ağırlıklı olarak Dr. Öğr. Üyesi danışmanlığında yazılmıştır.

Muhasebe eğitimi ile ilgili yazılan lisansüstü tezlerin danışmanlarına dair belirtilmesi gereken noktalardan biri de 97 tez içinde; bir öğretim üyesinin 3 teze, 10 öğretim üyesinin 2 teze, 74 öğretim üyesinin ise bir teze danışmanlık yapmış olmasıdır.

Lisansüstü tezlerin sayfa sayıları ile ilgili dağılım; 100 sayfadan az, 100-200 sayfa arası ve 200 sayfadan fazla şeklinde incelendiğinde Tablo 6'daki görünüm ortaya çıkmaktadır.

Tablo 6. Muhasebe Eğitimi ile İlgili Lisansüstü Tezler: Sayfa Sayısı

\begin{tabular}{|l|c|c|c|}
\hline \multirow{2}{*}{ Sayfa Sayısı } & \multicolumn{3}{|c|}{ Frekans (\%) } \\
\cline { 2 - 4 } 100 sayfadan az & $8(\% 9,30)$ & 0 & $\begin{array}{c}8 \\
(\% 8,16)\end{array}$ \\
\hline $100-200$ sayfa aras1 & $74(\% 86,05)$ & $4(\% 33,3)$ & $\begin{array}{c}78 \\
(\% 79,59)\end{array}$ \\
\hline 200 sayfadan fazla & $4(\% 4,65)$ & $8(\% 66,7)$ & $\begin{array}{c}12 \\
(\% 12,25)\end{array}$ \\
\hline Toplam & $\mathbf{8 6}$ & $\mathbf{1 2}$ & $\mathbf{9 8}(\% \mathbf{1 0 0})$ \\
\hline
\end{tabular}

Tablo 6'da da görüldüğü üzere; muhasebe eğitimi ile ilgili lisansüstü tezlerden 8 tanesi 100 sayfanın altında yazılmış olup bunların hepsi de yüksek lisans tezidir. Tezlerin ağırlıklı olarak yazıldığı sayfa sayısı 100-200 sayfa aralığında olup bunlarında çoğunluğunu yüksek lisans tezleri oluşturmaktadır. 200'den fazla sayfaya sahip tez sayısı 12 olup bunların çoğunluğunu ise doktora tezleri oluşturmaktadır. En düşük sayfa sayısına sahip tez 2016 yılında yazılan 71 sayfalık bir yüksek lisans tezi iken en yüksek sayfa sayısına sahip tez ise 2011 yılında yazılan 351 sayfalık bir doktora tezidir.

\subsubsection{Tezlerin Yıllara Göre Dağılımı}

Muhasebe eğitimi ile ilgili yazılan ilk tez, Gonca Kılınç tarafından ODTÜ'de 1991 yılında Prof. Dr. Erkut Göktan danışmanlığında İngilizce olarak yazılan "The Integration of Microcomputers into the Accounting Education" (Mikrobilgisayarların Muhasebe Eğitimi ile Bütünleştirilmesi) isimli yüksek lisans tezidir. Muhasebe eğitimi ile ilgili ilk tezin yazıldığ 1991 y1lından 2020 yılında kadar olan süreç, 1991-1999, 2000-2009 ve 2010-2019 olarak üç dönem şeklinde ele alınmış olup bu dönemlerde muhasebe eğitimi ile ilgili yazılan tezlerin özellikleri muhtelif açılardan Tablo 7'deki ve Grafik 1'deki gibi dağılım göstermektedir. 
Tablo 7. Muhasebe Eğitimi ile İlgili Lisansüstü Tezlerin Dönemlere Göre Türü, Sayfa Sayısı ve Dili

\begin{tabular}{|l|c|c|c|c|c|c|}
\hline Dönem & Frekans (\%) & \multicolumn{2}{|c|}{ Tez Türü } & $\begin{array}{c}\text { Ortalama } \\
\text { Sayfa Sayıs }\end{array}$ & \multicolumn{2}{|c|}{ Tez Dili } \\
\hline 1991-1999 & $10(\% 10,20)$ & 9 YL & 1 DR & 156 sayfa & 8 TR & 2 İNG \\
\hline 2000-2009 & $18(\% 18,37)$ & 14 YL & 4 DR & 178 sayfa & 17 TR & 1 İNG \\
\hline $2010-2019$ & $70(\% 71,43)$ & 63 YL & 7 DR & 141 sayfa & 70 TR & - \\
\hline Toplam & $\mathbf{9 8}(\% 100)$ & $\mathbf{8 6}$ YL & $\mathbf{1 2 ~ D R}$ & $\mathbf{1 5 0}$ sayfa & $\mathbf{9 5}$ TR & 3 İNG \\
\hline
\end{tabular}

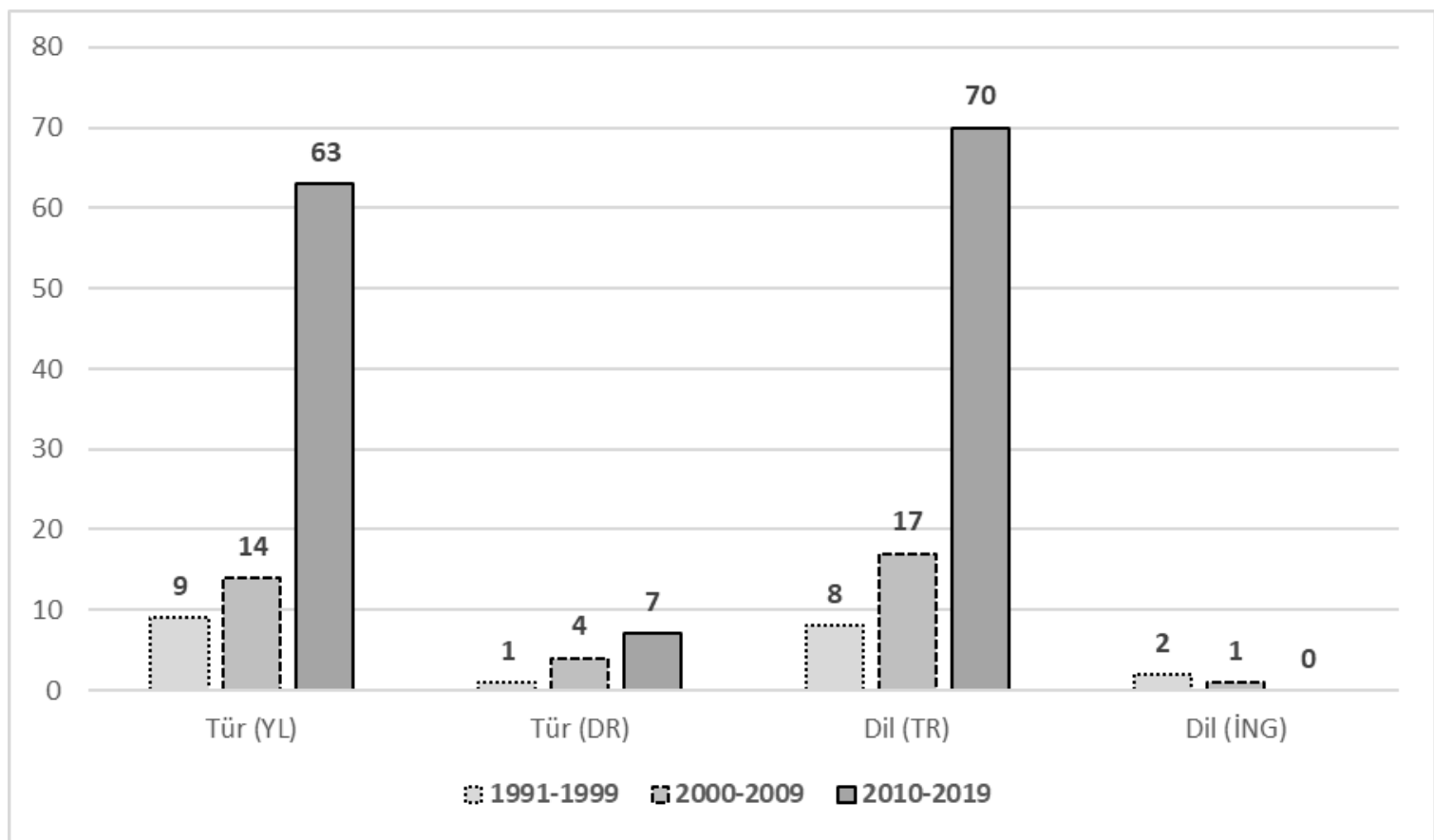

Grafik 1. Muhasebe Eğitimi ile İlgili Lisansüstü Tezlerin Dönemlere Göre Türü ve Dili

Tablo 7 ve Grafik 1'de de görüldüğü üzere; dönemler itibariyle geçmişten günümüze yazılan yüksek lisans ve doktora tezlerinin sayısında artış yaşanmakta olup yüksek lisanstaki artış dikkat çekmektedir. Tez sayısındaki artışa paralel olarak yazılan Türkçe tezlerde de artış gözlenmekte olup İngilizce yazılan tezlerde ise düşüş yaşanmıştır. Son on yıllık dönemde İngilizce olarak yazılan tez bulunmamaktadır. 30 senelik süreçte muhasebe eğitimi ile ilgili yazılan tezlerin yaklaşık \%72'si, 2010-2019 arası dönemde yazılmıştır. Toplam yazılan tez sayısı, dönemler itibariyle de artış göstermektedir.

Dönemler arasındaki yıllar açısından şu değerlendirme de yapılabilir: 1991-1999 arası dönemde; 1992 ve 1993 yıllarında tez yazılmamıştır. 1997 yılı ise 4 tez ile en fazla tezin yazıldığı yıldır. 2000-2009 arası dönemde; 2002 ve 2006 yıllarında tez yazılmamış olup, en fazla tez ise 4 tez ile 2007 ve 2008 yıllarında yazılmıştır. 2010-2019 arası dönemde; sadece 2012 yılında tez yazılmamış olup, en fazla tez ise 15 tez ile 2019 yılında yazılmıştır. 
İlgili tezlerin hangi unvandaki öğretim üyelerinin danışmanlığında yazıldığına bakıldığında Tablo 8'deki ve Grafik 2'deki görünüm ortaya çıkmaktadır. 1997 yılında yazılan bir teze ait danışmanlık bilgisine ulaşılamamıştır.

Tablo 8. Muhasebe Eğitimi ile İlgili Lisansüstü Tezlerin Dönemlere Göre Danışman Unvanı

\begin{tabular}{|l|c|c|c|c|}
\hline \multirow{2}{*}{ Dönem } & \multirow{2}{*}{ Frekans (\%) } & \multicolumn{3}{|c|}{ Danışman Unvanı } \\
\cline { 3 - 5 } & & Prof. Dr. & Doç. Dr. & $\begin{array}{c}\text { Dr. Öğgr. } \\
\text { Üyesi }\end{array}$ \\
\hline $1991-1999$ & $10(\% 10,20)$ & 6 & 1 & 2 \\
\hline $2000-2009$ & $18(\% 18,37)$ & 10 & 4 & 4 \\
\hline $2010-2019$ & $70(\% 71,43)$ & 17 & 25 & 28 \\
\hline Toplam & $\mathbf{9 8}(\% 100)$ & 33 & 30 & 34 \\
\hline
\end{tabular}

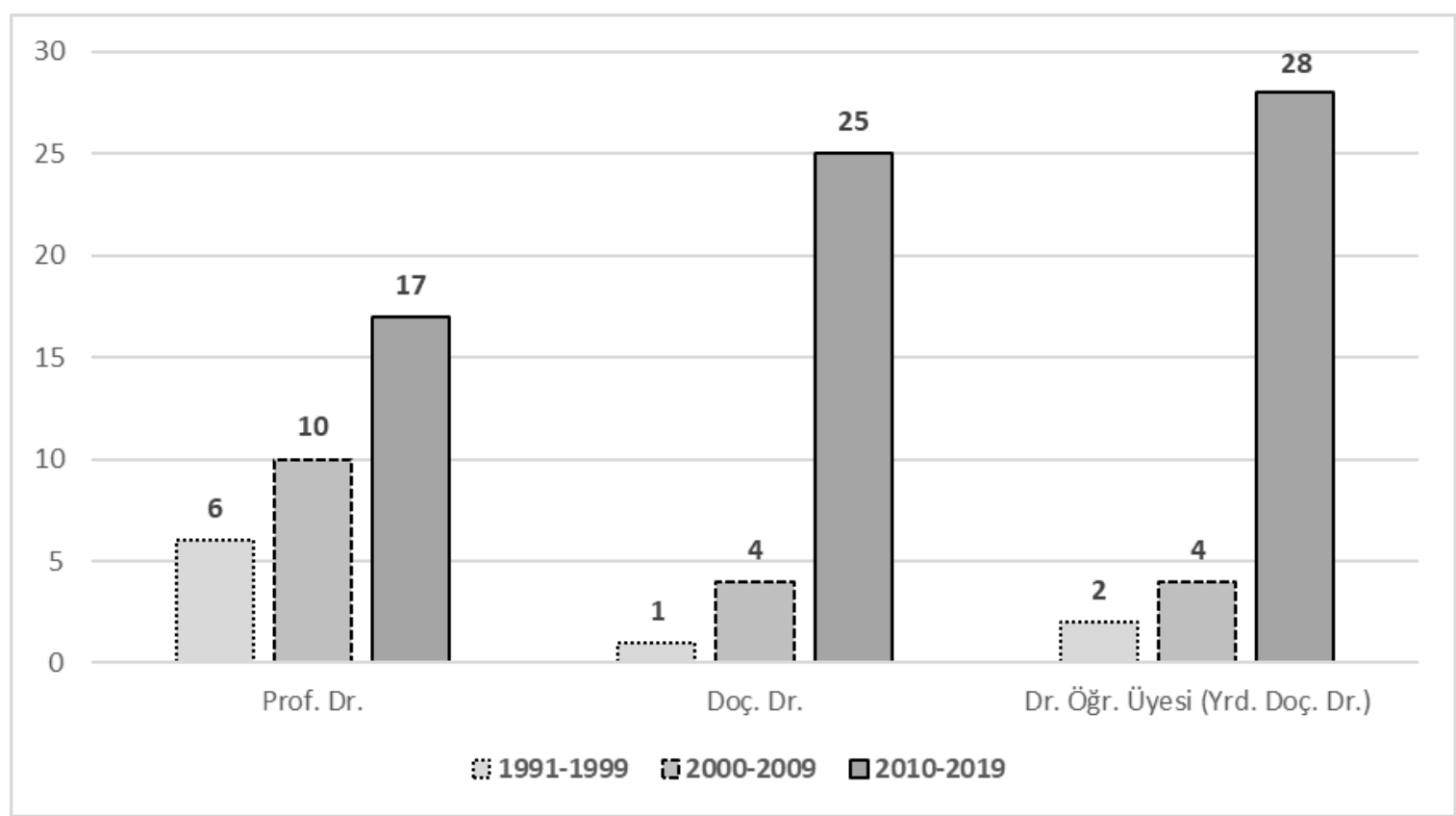

Grafik 2. Muhasebe Eğitimi ile İlgili Lisansüstü Tezlerin Dönemlere Göre Danışman Unvanı

Tablo 8 ve Grafik 2'de de görüldüğü üzere; muhasebe eğitimi ile ilgili yazılan tezlere dönemler itibariyle artan sayıda Prof. Dr., Doç. Dr. ve Dr. Öğr. Üyesi danışmanlıkta bulunmuştur. En çok danışmanlık artışı ise Dr. Öğr. Üyesinde yaşanmıştır. Dikkat çeken noktalardan biri de 1991-1999 ve 2000-2009 dönemlerinde yazılan tezlerde en çok Prof. Dr. danışmanlığı bulunurken bu durum 2010-2019 arası dönemde değişmiş ve en çok Dr. Öğr. Üyesi danışmanlığında tez yazılııştır. 


\subsubsection{Tezlerin Üniversitelere, Bölgelere, Enstitülere, Anabilim ve Bilim Dallarına Göre Dağılımı}

Muhasebe eğitimi ile ilgili yazılan lisansüstü tezlerin üniversite dağılımına devletvakıf ayrımı açısından bakıldığında Tablo 9'da gösterilmiştir. Görüldüğü üzere tezlerin neredeyse tamamı devlet üniversitelerinde yazılmış olup muhasebe eğitimi ile ilgili tezlerin yazıldığı vakıf üniversiteleri; Hasan Kalyoncu, Türk Hava Kurumu ve İstanbul Aydın Üniversitesi'dir.

Tablo 9. Muhasebe Eğitimi ile İlgili Lisansüstü Tezler:

Üniversite Türü (Devlet \& Vakıf)

\begin{tabular}{|l|c|}
\hline Üniversite Türü & Frekans (\%) \\
\hline Devlet Üniversiteleri & $95(\% 96,94)$ \\
\hline Vakıf Üniversiteleri & $3(\% 03,06)$ \\
\hline Toplam & $\mathbf{9 8}(\% 100)$ \\
\hline
\end{tabular}

Devlet üniversitelerinde yazılan 95 lisansüstü tez; 45 farklı üniversitede yazılmıştır. Söz konusu üniversitelere ilişkin bilgiler aşağıda yer alan tablolardaki gibidir. İki ve üstü tezin yazıldığ 1 üniversiteler Tablo 10'da bir tezin yazıldığı üniversiteler ise Tablo 11 'dedir.

Tablo 10. Muhasebe Eğitimi ile İlgili Lisansüstü Tezler: Devlet Üniversiteleri (2 ve üstü tez)

\begin{tabular}{|l|c|l|c|}
\hline Üniversite & Tez Sayısı & Üniversite & Tez Sayısı \\
\hline Gazi & 7 & İstanbul & 3 \\
\hline Sakarya & 7 & Marmara & 3 \\
\hline Karadeniz Teknik & 5 & Muğla Sıtkı Koçman & 3 \\
\hline Selçuk & 5 & Süleyman Demirel & 3 \\
\hline Anadolu & 4 & Bülent Ecevit & 2 \\
\hline Atatürk & 4 & Gümüşhane & 2 \\
\hline Dumlupınar & 4 & Kafkas & 2 \\
\hline Kahramanmaraş Sütçü İmam & 4 & Niğde Ömer Halisdemir & 2 \\
\hline Bilecik Şeyh Edebali & 3 & Orta Doğu Teknik & 2 \\
\hline Burdur Mehmet Akif Ersoy & 3 & Ondokuz Mayıs & 2 \\
\hline Toplam & \multicolumn{3}{|l}{} \\
\hline
\end{tabular}

Tablo 10'da da görüldüğü üzere; muhasebe eğitimi ile ilgili iki ve üstü lisansüstü tezin yazıldığı 20 farklı üniversite mevcuttur. Bu üniversiteler arasında muhasebe eğitimi ile ilgili en çok tez, 7 tez ile Gazi ve Sakarya Üniversitesi'nde yazılmıştır. 
Tablo 11. Muhasebe Eğitimi ile İlgili Lisansüstü Tezler:

Devlet Üniversiteleri (1 tez)

\begin{tabular}{|c|c|c|}
\hline \multicolumn{3}{|l|}{ Üniversite } \\
\hline Abant İzzet Baysal & \multicolumn{2}{|l|}{ Firat } \\
\hline Afyon Kocatepe & \multicolumn{2}{|l|}{ Giresun } \\
\hline Ağrı İbrahim Çeçen & \multicolumn{2}{|l|}{ Hitit } \\
\hline Aksaray & \multicolumn{2}{|l|}{ İnönü } \\
\hline Ankara & \multicolumn{2}{|l|}{ Karabük } \\
\hline Balıkesir & \multicolumn{2}{|l|}{ Kayseri } \\
\hline Bartın & \multicolumn{2}{|c|}{ Manisa Celal Bayar } \\
\hline Boğaziçi & \multicolumn{2}{|l|}{ Mersin } \\
\hline Çanakkale Onsekiz Mart & \multicolumn{2}{|c|}{ Pamukkale } \\
\hline Çankırı Karatekin & \multicolumn{2}{|c|}{ Sivas Cumhuriyet } \\
\hline Dicle & \multicolumn{2}{|l|}{ Trakya } \\
\hline Dokuz Eylül & \multicolumn{2}{|c|}{ Zonguldak Karaelmas } \\
\hline Eskişehir Osmangazi & Toplam & 25 \\
\hline
\end{tabular}

Muhasebe eğitimi ile ilgili tezlerin yazıldığı üniversitelerin bulunduğu coğrafi bölgelerin dağılımı, Tablo 12'de gösterilmektedir.

Tablo 12. Muhasebe Eğitimi ile İlgili Lisansüstü Tezler:

\begin{tabular}{|l|c|}
\multicolumn{1}{l}{ Üniversitenin Yer Aldığı Bölge } \\
\hline Bölge & Frekans (\%) \\
\hline İç Anadolu & $27(\% 27,56)$ \\
\hline Marmara & $21(\% 21,43)$ \\
\hline Karadeniz & $17(\% 17,35)$ \\
\hline Akdeniz & $11(\% 11,22)$ \\
\hline Ege & $11(\% 11,22)$ \\
\hline Doğu Anadolu & $9(\% 09,18)$ \\
\hline Güneydoğu Anadolu & $2(\% 02,04)$ \\
\hline Toplam & $\mathbf{9 8}(\% 100)$ \\
\hline
\end{tabular}

Tablo 12'den görüldüğü üzere; tezler Türkiye'nin 7 farklı bölgesinde de yazılmış olup; en fazla tez İç Anadolu ile Marmara bölgesinde yer alan üniversitelerde, en az tez ise Doğu Anadolu ve Güneydoğu Anadolu bölgesinde yer alan üniversitelerde yazılmıştır.

Muhasebe eğitimi ile yazılan lisansüstü tezlerin üniversitelerin hangi enstitülerinde bulunduğuna dair dağılım, Tablo 13'te verilmektedir. 
Tablo 13. Muhasebe Eğitimi ile İlgili Lisansüstü Tezler: Enstitü

\begin{tabular}{|l|c|}
\hline Enstitü & Frekans (\%) \\
\hline Sosyal Bilimler & $91(\% 92,86)$ \\
\hline Eğitim Bilimleri & $4(\% 04,08)$ \\
\hline Fen Bilimleri & $1(\% 01,02)$ \\
\hline İşletme & $1(\% 01,02)$ \\
\hline Lisansüstü Eğitim & $1(\% 01,02)$ \\
\hline Toplam & $\mathbf{9 8}(\mathbf{\% 1 0 0 )}$ \\
\hline
\end{tabular}

Tablo 13 'te görüldügü gibi tezler 5 farklı enstitü bünyesinde yazılmış olup en çok tez 91 tez ile Sosyal Bilimler Enstitüsünde, en az tez ise birer tez ile Fen Bilimleri, İşletme ve Lisansüstü Eğitim Enstitüsünde yazılmıştır. Ayrıca 12 doktora tezinin tamamı, Sosyal Bilimler Enstitüsü bünyesinde yazılmıştır.

Muhasebe eğitimi ile ilgili yazılan lisansüstü tezlere ait 98 tezden 12'sinde anabilim dalı bilgisi yer almamaktadır. Geriye kalan 86 teze ait anabilim dalı dağılımı Tablo 14'teki gibidir.

Tablo 14. Muhasebe Eğitimi ile İlgili Lisansüstü Tezler: Anabilim Dalı

\begin{tabular}{|l|c|}
\hline Anabilim Dalı & Frekans (\%) \\
\hline İşletme & $74(\% 86,05)$ \\
\hline İşletme Eğitimi & $4(\% 04,65)$ \\
\hline Muhasebe ve Finansal Yönetim & $3(\% 03,49)$ \\
\hline Muhasebe ve Finans Yönetimi & $2(\% 02,33)$ \\
\hline Muhasebe ve Finansman & $1(\% 01,16)$ \\
\hline Orman Mühendisliği & $1(\% 01,16)$ \\
\hline Yönetim Bilimleri & $1(\% 01,16)$ \\
\hline Toplam & $\mathbf{8 6}(\% 100)$ \\
\hline
\end{tabular}

Tablo14'te yer aldığı üzere tezler 7 farklı anabilim dalında yazılmış olup en fazla tez 74 tez ile İşletme Anabilim Dalında, en az tez ise birer tez ile Muhasebe ve Finansman, Orman Mühendisliği ve Yönetim Bilimleri Anabilim Dallarında yazılmıştır.

Muhasebe eğitimi ile ilgili yazılan lisansüstü tezlere ait 98 tezden 47'sinde bilim dalı bilgisi yer almamaktadır. Geriye kalan 51 teze ait bilim dalı dağılımı Tablo 15 'teki gibidir. 
Tablo 15. Muhasebe Eğitimi ile İlgili Lisansüstü Tezler: Bilim Dalı

\begin{tabular}{|l|c|}
\hline Bilim Dalı & Frekans (\%) \\
\hline Muhasebe Finansman & $28(\% 54,90)$ \\
\hline Muhasebe & $8(\% 15,69)$ \\
\hline İşletme & $8(\% 15,69)$ \\
\hline İşletme Eğitimi & $2(\% 03,92)$ \\
\hline Yönetim ve Organizasyon & $2(\% 03,92)$ \\
\hline Genel İşletme & $1(\% 01,96)$ \\
\hline Muhasebe ve Denetim & $1(\% 01,96)$ \\
\hline Muhasebe ve Finans Yönetimi & $1(\% 01,96)$ \\
\hline Toplam & $\mathbf{5 1}(\% 100)$ \\
\hline
\end{tabular}

Tablo 15 'te de görüldügü üzere, muhasebe eğitimi ile ilgili lisansüstü tezlerde bilim dalı bilgisine ulaşılan 51 tez, 8 farklı bilim dalında yazılmıştır. En fazla tez 28 tez ile Muhasebe Finansman Bilim Dalında yazılmış olup en az tez ise birer tez ile Genel İşletme, Muhasebe ve Denetim ile Muhasebe ve Finans Yönetimi bilim dallarında yazılmıştır. 47 teze ait verinin olmayışının da bu tabloyu etkilediği ifade edilebilir.

\subsubsection{Tezlere Ait Dizin ve Anahtar Kelimeler}

Muhasebe eğitimi ile ilgili ulaşılan 98 tezden 4 tezde dizin ve anahtar kelimelere ait verinin bulunmamasından dolayı geriye kalan 94 tez üzerinden dizin ve anahtar kelimelere ilişkin değerlendirmede bulunulmuştur. Söz konusu 94 teze ait dizin ve anahtar kelimeler verilerinde; 82 farklı ifade çerçevesinde toplamda 321 ifade kullanılmıştır.

Muhasebe eğitimi ile ilgili lisansüstü tezlere ait dizin ve anahtar kelimeler değerlendirildiğinde en çok ve en az kullanılan kelimeler Tablo 16 ve Tablo 17'deki gibidir.

Tablo 16. Muhasebe Eğitimi ile İlgili Lisansüstü Tezler: Dizin ve Anahtar Kelimeler (10 üstü)

\begin{tabular}{|l|c|}
\hline Dizin - Anahtar Kelime & Frekans \\
\hline Muhasebe Eğitimi & 78 \\
\hline Muhasebe & 24 \\
\hline Mesleki Eğitim & 15 \\
\hline Meslek Liseleri & 14 \\
\hline Muhasebeci & 13 \\
\hline Ticaret Liseleri & 11 \\
\hline Eğitim & 11 \\
\hline Toplam & $\mathbf{1 6 6}$ \\
\hline
\end{tabular}


Tablo 16 'da görüldüğü üzere muhasebe eğitimi ile ilgili tezlerde beklendiği gibi en çok muhasebe eğitimi ve muhasebe kelimeleri kullanılmıştır. Bu kelimelerden sonra ise en çok mesleki eğitim, meslek liseleri, muhasebeci, ticaret liseleri ve eğitim kelimeleri kullanılmıştır.

Tablo 17. Muhasebe Eğitimi ile İlgili Lisansüstü Tezler:

Dizin ve Anahtar Kelimeler (10 altı)

\begin{tabular}{|c|c|c|c|}
\hline Dizin - Anahtar Kelime & Frekans & Dizin - Anahtar Kelime & Frekans \\
\hline Üniversiteler & 9 & Ters-Yüz Sınıf & 1 \\
\hline Meslek Yüksek Okulları & 7 & Mesleki Eğitim Merkezleri & 1 \\
\hline Üniversite Öğrencileri & 6 & Denetim & 1 \\
\hline TMS/TFRS & 6 & Kurumsal Yönetim & 1 \\
\hline Hile & 5 & Kurumsal Yönetim Endeksi & 1 \\
\hline Öğrenciler & 5 & Muhasebe Hukuku & 1 \\
\hline İşletmeler & 5 & Programlama & 1 \\
\hline Uluslararası Muhasebe Standartları & 5 & Yükseköğretim & 1 \\
\hline İş Ahlak1 & 5 & Bilgisayar & 1 \\
\hline Mesleki ve Teknik Anadolu Lisesi & 4 & Bilgisayar Kullanımı & 1 \\
\hline Adli Muhasebe & 4 & Personel Seçimi & 1 \\
\hline Genel Muhasebe & 4 & İhtiyaç Belirleme & 1 \\
\hline Muhasebe Uygulamaları & 4 & İhtiyaçlar & 1 \\
\hline Bilgisayar Destekli Eğitim & 3 & İş Değerlemesi & 1 \\
\hline Eğitim Teknolojisi & 3 & İstihdam & 1 \\
\hline Ortaöğretim Kurumları & 3 & İş Programı & 1 \\
\hline İşletme Eğitimi & 3 & İşe Alma & 1 \\
\hline Etik & 3 & Meslek Lisesi Öğrencileri & 1 \\
\hline Anadolu Meslek Liseleri & 3 & Lise Öğretmenleri & 1 \\
\hline Muhasebe Mesleği & 2 & Mesleki Teknik Eğitim & 1 \\
\hline Ĕgitim Yöntemleri & 2 & İstihdam & 1 \\
\hline Öğretim Yöntemleri & 2 & Finansal Tablolar & 1 \\
\hline Uluslararası Muhasebe Eğitimi Standartları & 2 & İşletme Eğitimi & 1 \\
\hline Lise Öğrencileri & 2 & Görsel Materyaller & 1 \\
\hline Öğretim Sorunları & 2 & Öğrenci Başarısı & 1 \\
\hline İşletme & 2 & Girişimcilik & 1 \\
\hline UFRS & 2 & Meslek Ahlakı & 1 \\
\hline Uluslararas1 Muhasebe & 2 & İş Hayatı & 1 \\
\hline Finansal Raporlar & 2 & Beklenti & 1 \\
\hline Meslek Ahlak1 & 2 & Otomasyon & 1 \\
\hline Motivasyon & 2 & Teknoloji Kullanımı & 1 \\
\hline Ekonomik Gelişmeler & 1 & Simülasyon & 1 \\
\hline İran & 1 & Hamidiye Ticaret Mektubu & 1 \\
\hline Uzaktan Öğretim & 1 & MEGEP & 1 \\
\hline Bilgisayarlı Muhasebe Sistemi & 1 & Aktif Öğrenme Yöntemleri & 1 \\
\hline Almanya & 1 & Öğrenci tutumu & 1 \\
\hline Staj & 1 & Modern eğitim & 1 \\
\hline Eğitim Araçları & 1 & Toplam & 155 \\
\hline
\end{tabular}

Tablo 17'den de görüleceği üzere muhasebe eğitimi ile ilgili birçok muhtelif ifade ilişkilendirilmiş ve tezlerde dizin ya da anahtar kelime olarak kullanılmıştır.

Bir diğer taraftan muhasebe eğitimi ifadesinin tezlerin başlık, dizin ve özet kısmında hangi düzeyde yer aldığına dair görünüm Tablo 18'deki gibidir. 
Tablo 18. Muhasebe Eğitimi ile İlgili Lisansüstü Tezler: Başlık, Dizin ve Özet (Muhasebe Ĕ̈itimi Iffadesi)

\begin{tabular}{|c|c|c|c|c|}
\hline & Mevcut & $\begin{array}{c}\text { Mevcut } \\
\text { Değil }\end{array}$ & $\begin{array}{l}\text { Hiçbir Veri } \\
\text { Girilmemiş }\end{array}$ & Toplam \\
\hline Başlık & 59 & 39 & - & 98 \\
\hline Dizin & 69 & 13 & 16 & 98 \\
\hline Özet & 83 & 14 & 1 & 98 \\
\hline
\end{tabular}

Tablo 18'de görüldüğü üzere muhasebe eğitimi ifadesi; 59 tezin başlığında, 69 tezin dizin kısmında ve 83 tezin de özet kısmında kullanılmıştır. Önemli noktalardan biri de 98 tezden birinde özet kısmında, 16'sının ise dizin kısmında herhangi bir ifadenin yer almaması bir başka ifade ile boş bırakılmış olmasıdır.

\subsubsection{Tezlerin Araştırma Kaynakları ve Yöntemleri}

Muhasebe eğitimi ile ilgili 98 tezden 17'sine (2 doktora, 15 yüksek lisans tezi) erişim kısıtlı olduğu için geriye kalan 81 tezin (10 doktora, 71 yüksek lisans tezi) araştırmalarına ilişkin kaynak toplama yöntemleri tezlerin ilgili kısımlarına ulaşılarak analiz edilmiştir. Ulaşılan sonuçlara ait görünüm Tablo 19'da sunulmaktadır.

Tablo 19. Muhasebe Eğitimi ile İlgili Lisansüstü Tezlerin Kaynak Toplama Yöntemleri

\begin{tabular}{|l|c|c|c|}
\hline Tezlere Ait Araştırmaların Kaynakları & Frekans (\%) & \multicolumn{2}{|c|}{ Tez Türü } \\
\hline Birincil kaynak (anket, çalışma grubu, vb.) & $73(\% 90,12)$ & 65 YL & 8 DR \\
\hline İkincil kaynak (müfredat, işletme tabloları, kurum verileri, vb.) & $8(\% 09,88)$ & $6 \mathrm{YL}$ & 2 DR \\
\hline Toplam & $\mathbf{8 1}(\% \mathbf{1 0 0})$ & $\mathbf{7 1 ~ Y L}$ & $\mathbf{1 0 ~ D R}$ \\
\hline
\end{tabular}

Tezlerin araştırma kısımlarında kullandıkları kaynakları toplama yöntemlerini gösteren Tablo 19'da da görüldüğü üzere 73 tezde anket ve çalışma grubu gibi birincil kaynaklardan, 8 tezde ise müfredat, işletme tabloları ve kurum verileri gibi ikincil kaynaklardan yararlanılmıştır. Birincil kaynaktan yararlanan 73 tezin 72 'si anket, 1'i ise grup çalışması yöntemi ile elde ettiği verileri araştırma amacı çerçevesinde kullanmıştır.

Anket kullanan 10 tezde birden fazla anket uygulaması yapılmış olup bunların 8'inde iki farklı anket uygulanırken, 1 tanesinde üç ve 1 tanesinde de beş farklı anket uygulaması yapılmıştır. Anketlerde ağırlıklı olarak 5'li Likert ölçeği kullanılırken 3'lü, 4'lü ve 9'lu Likert ölçeği kullanıp açık ve kapalı uçlu ile çoktan seçmeli sorular bulunmaktadır. Ayrıca 1 tezde anket yanında odak grup çalışmasından da yararlanılmıştır. Diğer taraftan anketlerin analiz edildiği programlara ilişkin 12 tezde herhangi bir bilgi verilmemiştir. 1 tezde hem Excel hem de SPSS kullanılırken, diğer 59 ankette ise sadece SPSS programı kullanılmıştır. Ayrıca anketler, yüz yüze ve/veya internet olmak üzere iki farklı araç ile öğrenci, öğretmen, akademisyen ve farklı ilgililere ulaştırılmış ve cevaplar toplanmıştır. 
İkincil kaynak kullanan araştırmalar içinde 4'ü müfredat, 1'i kurum verileri, 1'i işletme verileri, 2'si de tarihsel süreçleri ele alarak çalışmalarını gerçekleştirmiştir. Doktora çalışmaları özelinde ise ikincil kaynak kullanan 2 çalışmadan birinde müfredat birinde de tarihsel süreç ele alınarak araştırma yapılmıştır. Birincil kaynak kullanan 8 doktora tezinden 7’sinde anket 1'inde ise çalışma grubu verilerinden yararlanılmıştır.

Birincil ve ikincil kaynaktan elde edilen veriler, 81 çalışmanın 79'unda muhtelif istatiksel yöntemler (Anova, $t$ testi, regresyon, korelasyon, faktör, içerik analizi $v b$.) kullanılarak analiz edilmiş olup çalışma sonucunda çeşitli çıkarımlar ve değerlendirmelerde bulunulmuştur. Geriye kalan 2 çalışmada ise ikincil kaynaklar yardımı ile tarihsel süreçler ele alınarak nitel değerlendirmelerde bulunulmuştur.

Muhasebe eğitimi ilgili tezlerin birincil ve ikincil araştırma kaynakları ile kısıtlı ve toplam tez sayısının dönemler itibariyle görünümü Grafik 3'te gösterilmektedir.

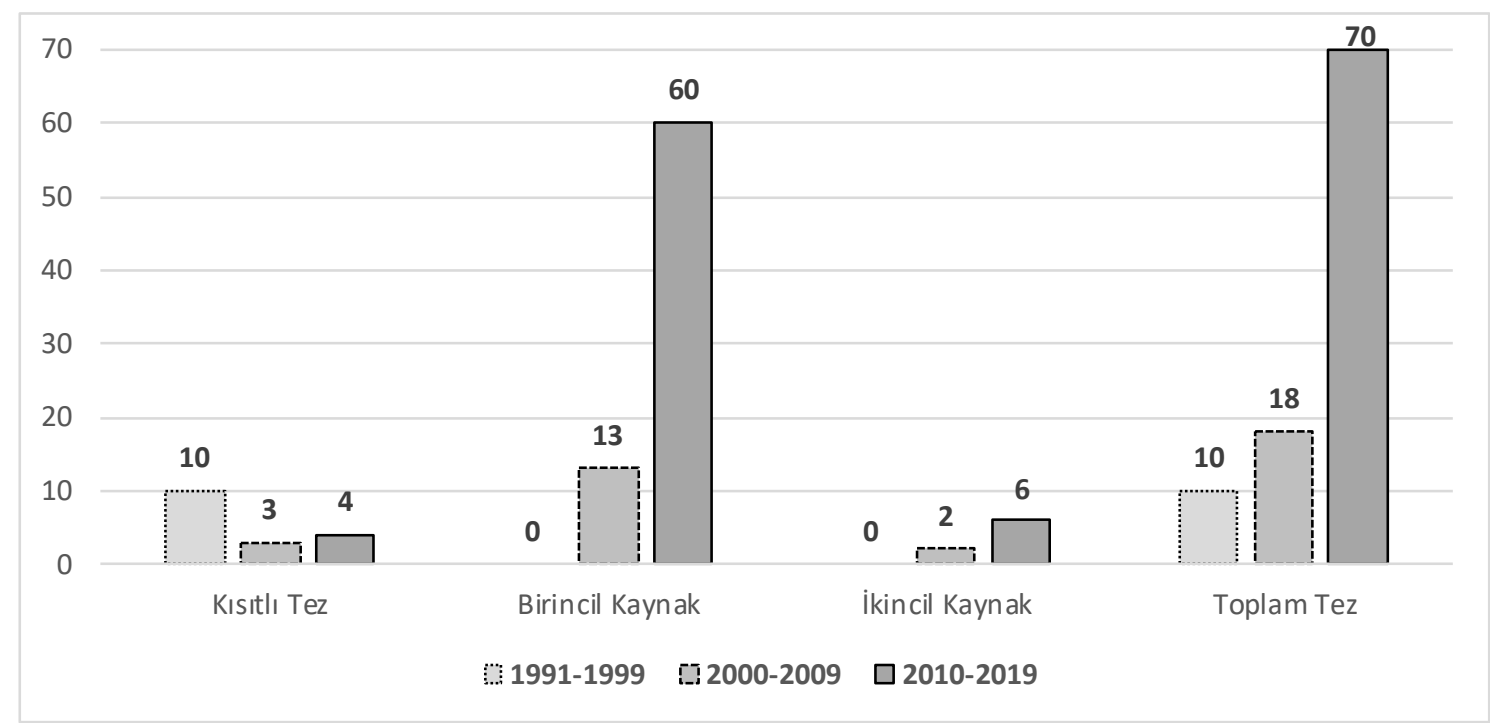

Grafik 3. Dönemlere Göre Tezlerin Kaynak Toplama Yöntemleri

Grafik 3'ten de görüldüğü üzere, birincil kaynak kullanımı 2010-2019 döneminde yazılan tezlerin artmasına paralel olarak büyük bir artış göstermiş olup aynı şekilde ikincil kaynakların kullanımı da yüzdesel olarak büyük bir artış göstermiştir. 1991-1999 dönemindeki 10 tezde kısıtlı olduğundan bu tezlerin araştırmalarında kullandıkları birincil ve ikincil kaynakların dağılımı detaylı bir şekilde incelenememiştir.

Ankete katılan kişi sayılarının dağılımı incelendiğinde Grafik 4’teki görünüm ortaya çıkmaktadır. Grafikten görüldüğü üzere, 22 ankette katılımcı sayısının 101-200 arasında olduğu gözlenmiştir. Bunu 13 anket ile 201-300 katılımc1 ve 11 anket ile 500'den fazla katılımcının olduğu anketler izlemektedir. En az katılımcı sayısı 10, en fazla katılımcı sayısı ise 2.502 kişidir. Anketlere ortalama 334 kişi katılım göstermiştir. 


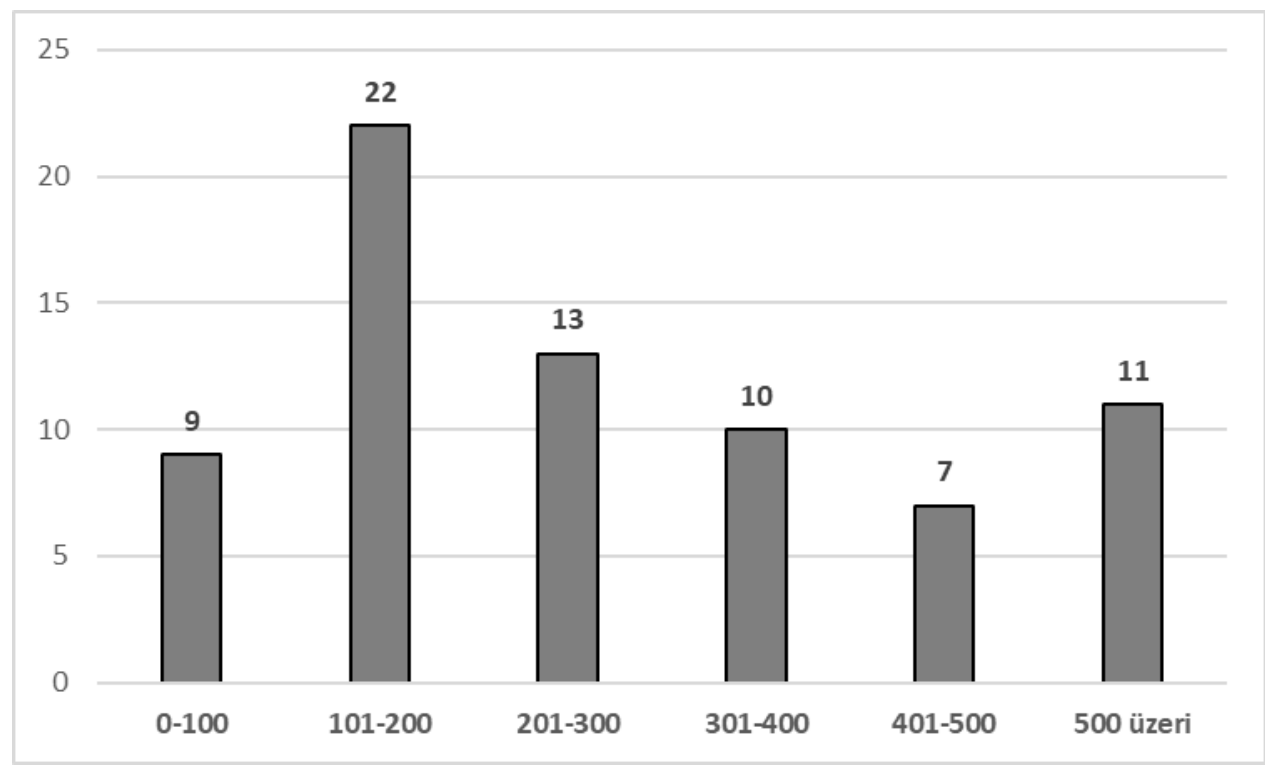

Grafik 4. Ankete Katılan Kişi Sayısının Dağılımı

Anketlerde yer alan soru sayılarının dağılımı Grafik 5'te verilmektedir. Yapılan anketlerdeki soru sayıları incelendiğinde, soru sayılarının ağırlıklı olarak 11 ile 40 arasında kümelendiği, en fazla kümelenmenin ise 21-30 aralığında olduğu görülmektedir. Anketler en az soru sayısı 4 , en fazla soru sayısı ise 180 'dir. Anketlerde ortalama 34 soru sorulmuştur.

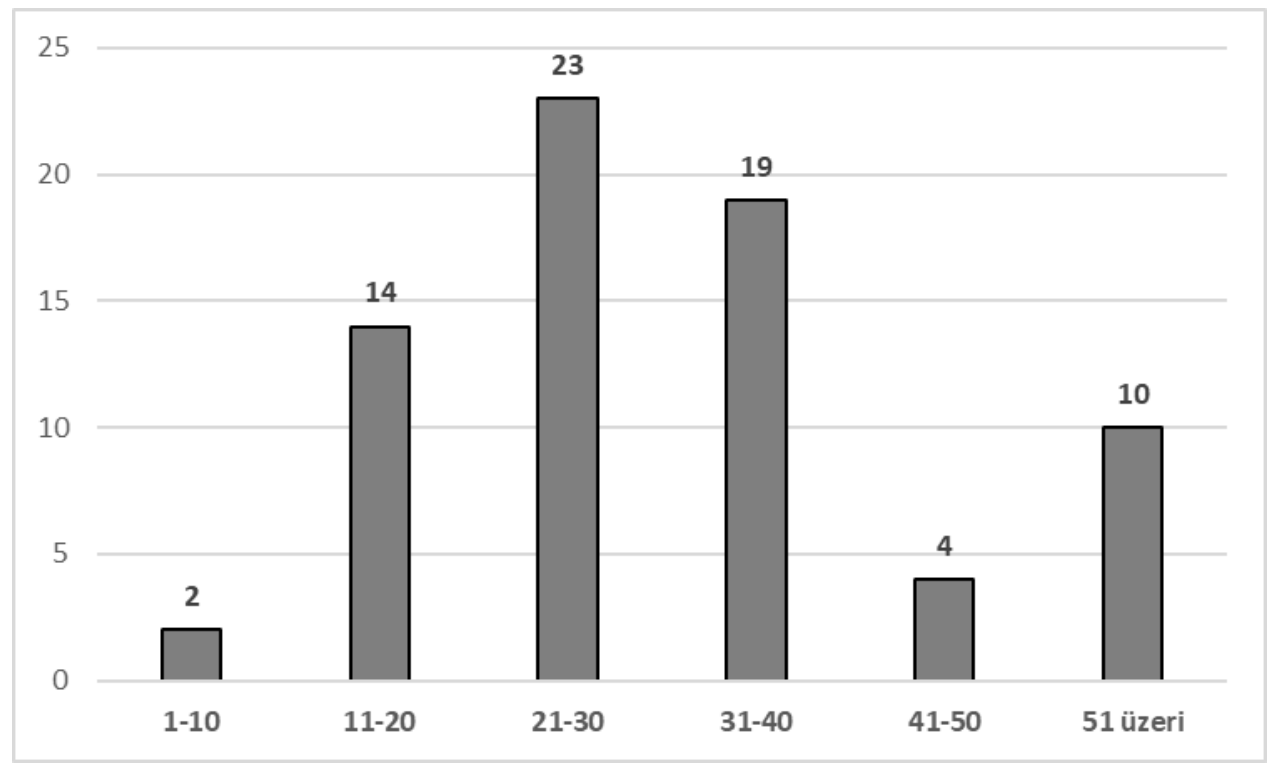

Grafik 5. Ankette Yer Alan Soru Sayısının Dağılımı

Anketin kullanıldığı 72 tezde oluşturulan hipotez sayıları Grafik 6' da gözükmektedir. 


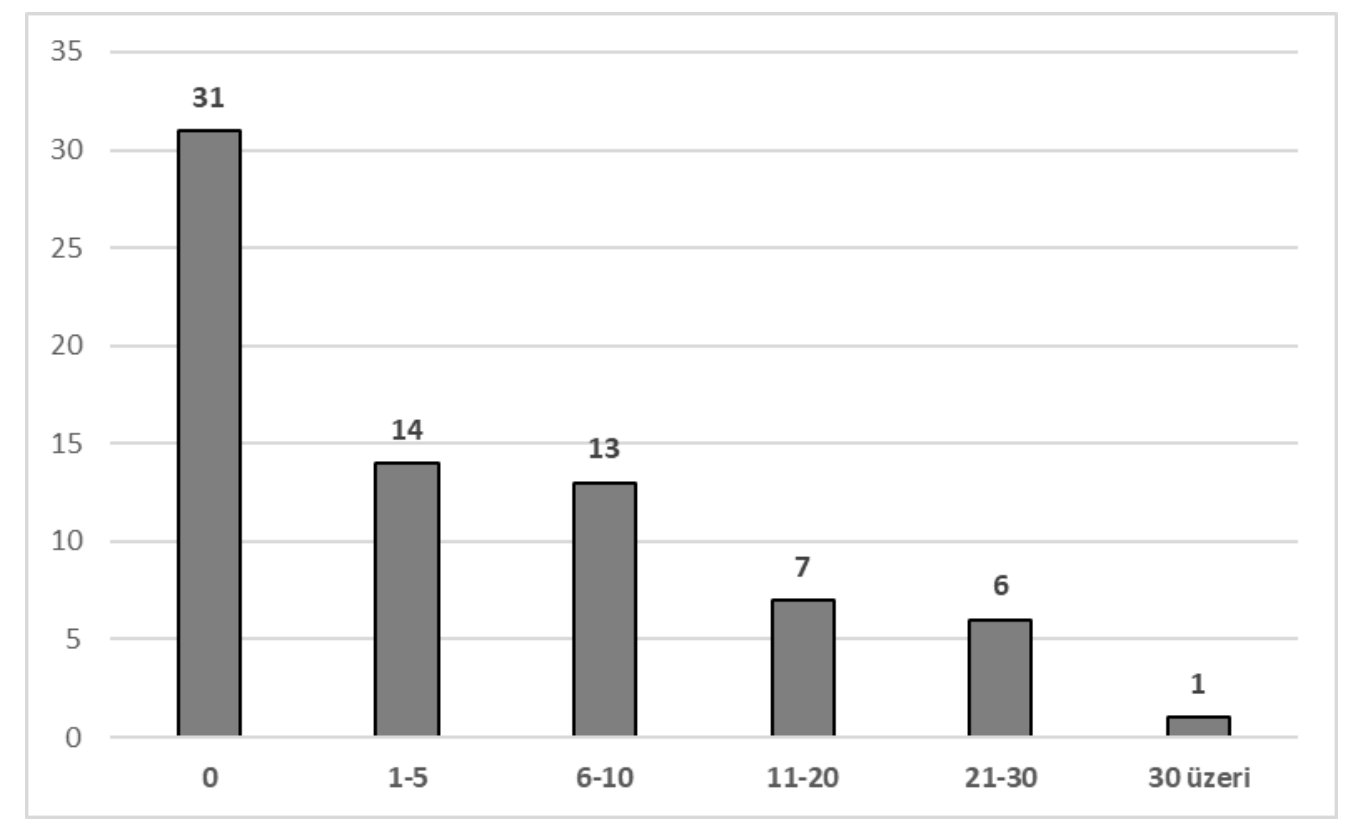

Grafik 6. Anket Kullanılan Tezlerde Kurulan Hipotez Sayısının Dağılımı

Grafik 6’ya göre 31 tezde hiç hipotez geliştirilmemiştir. Hipotez geliştirilmeyen tezlerde yer alan anketlerin sonuçları ağırlıklı olarak frekans analizi yardımı ile yorumlanmıştır. 14 tezde 5 'ten az sayıda hipotez kurulurken 13 tezde ise 6-10 arasında hipotez kurulmuştur. 7 tezde ise 11-20 arası, 6 tezde 21-30 arası, 1 tezde ise 30 üzeri hipotez geliştirilmiştir. Anket kullanan tezlerde en az 1, en çok ise 36 adet hipotez kurulmuştur. Sifır hipotezli çalışmalar hariç tutulduğunda 41 tezde ortalama olarak kullanılan hipotez sayısı 10’dur.

Anket kullanılan 7 doktora tezinin 4'ünde hiç hipotez geliştirilmemiş olup geriye kalan 3 tezde ise 6, 23 ve 36 hipotez geliştirilmiştir. Anket kullanan 65 yüksek lisans tezinin 27'sinde hiç hipotez geliştirilmemiş olup geriye kalan 38 tezde ise ortalama 9 hipotez geliştirilmiştir. Bu tezlerde en az 1, en fazla ise 30 hipotez kullanılmış ve test edilmiştir.

\section{SONUÇ VE ÖNERILER}

Muhasebe eğitimi, sadece eğitimi alan ve veren kişilerin kariyerleri açısından önem arz etmemekte söz konusu kişilerin çalıştıkları kurumlar, işletmeler ve dolayısıyla ülke ekonomisi açısından da önem teşkil etmektedir. Muhasebe eğitimin nasıl olacağına, neleri kapsayacağına ve hangi materyaller ile ilgililere ulaştırılacağına; konu hakkında yapılan konferanslar, sempozyumlar, tezler, makaleler vb. akademik çalışmaların yön verdiği ifade edilebilir.

YÖK Ulusal Tez Merkezinde kayıtlı bulunan muhasebe eğitimi ile ilgili 98 lisansüstü tezin incelendiği bu çalışma sonucunda ortaya çıkan bulgular bir bütün olarak ele alındığında aşağıda yer alan değerlendirmeler yapılabilmektedir:

$\checkmark$ 1991-2019 arasındaki süreçte analiz edilen üç farklı dönem boyunca muhasebe eğitimi ile ilgili yazılan tezlerin artma nedeni; son on beş yılda üniversite, öğretim üyesi ve 
lisansüstü öğrenci sayısının artışı ile ifade edilebilmektedir. Dönemler içerisinde yer alan yıllar değerlendirildiğinde ise muhasebe eğitimine lisansüstü tez çalışmaları açısından bazı yıllarda olan ilgi artmış bazı yıllarda da azalmıştır.

$\checkmark$ Literatür çalışmalarındaki bulgulardan hareketle muhasebe alanında yazılan tezlerde muhasebe eğitimi ile ilgili yazılan tezlerin çok düşük seviyede kaldığı da görülmektedir. Bunun nedeni olarak muhasebenin diğer alt alanlarındaki konuların popüler olması, danışmanların yönlendirmesi ve benzeri unsurların etkili olduğu ifade edilebilir.

Literatür ve bu çalışmadan hareketle, muhasebe eğitimi ile ilgili olarak lisansüstü tez kapsamında ağırlıklı olarak mesleki ve Anadolu liseleri ile meslek yüksekokulları ve üniversitelere yönelik anket çalışmalarına ağırlık verildiği fakat güncel gelişmelere ve teknolojik değişimlere yönelik konuların (ters-düz sınıf, eğitim materyalleri, mobil teknoloji, yapay zekâ, vb.) muhasebe eğitimine olası etkileri gibi farklı konularda fazla çalışmanın olmadığı ifade edilebilir. Bununla birlikte söz konusu hususlar, diğer akademik çalışmalar olan makale, bildiri vb. kapsamında daha fazla ele alınmaktadır.

$\checkmark \quad$ Tezlerde ağırlıklı olarak mesleki eğitim, meslek liseleri, ticaret liseleri ve meslek yüksek okulları kapsamında çalışmalar mevcuttur. Ancak muhasebe eğitiminin daha kapsayıcı ve güncel bir şekilde verilmesi gereken kurumlar olan üniversitelere yönelik daha az sayıda lisansüstü çalışma bulunmaktadır. Alkan'ın 2014 yılında yaptığı araştırmanın sonuçları da bu durumu desteklemektedir. $\mathrm{Bu}$ çerçevede muhasebe eğitimi ile ilgili olarak yükseköğretim kurumlarındaki muhasebe eğitimini konu alan daha fazla tez çalışmasının yapılması gerekliliğinden söz edilebilir.

$\checkmark$ Tarihsel süreç içindeki artış doğrultusunda gelecek yıllarda muhasebe eğitimi ile ilgili daha fazla doktora çalışmasının yapılarak muhasebe eğitimine yön verebilecek çalışmaların ortaya konması sağlanabilir.

Muhasebe ile ilgili artan oranda öğrenci sayısı ve lisansüstü programa sahip olan vakıf üniversitelerinin de muhasebe eğitimi ile ilgili olarak daha fazla çalışma ortaya koyması beklenebilir.

Ortaya konulan bulgular doğrultusunda yapılan değerlendirmeler ile birlikte muhasebe eğitimi ile ilgili gelecekte tez konusu olarak çalışılabilecek ya da diğer akademik çalışmalarda bulunacak araştırmacılara yönelik konu önerileri ise şu şekilde ifade edilebilmektedir:

$\checkmark \quad$ Yükseköğretim düzeyinde verilen muhasebe eğitimi ile ilgili yapılan tezlerin azlığı bu konu ve ilişkili konularda yapılacak çalışmaların önemini göstermektedir. Bu çerçevede lisans ve lisansüstü düzeyde muhasebe eğitimi konusunun farklı açılardan ele alınarak çalışılabileceği ifade edilebilir.

Araştırma kaynağı bakımından ağırlıklı olarak kullanılan anket ile birlikte farklı kaynaklardan elde edilen veriler 1şı̆̆ında da muhasebe eğitimi ile ilgili tezlerin yazılması, ilgili alana çeşitlilik getirerek geleceğe yönelik farklı çıkarımların yapılması sağlanabilir. 
$\checkmark$ Muhasebeden ayrı olarak eğitim alanında yaşanan gelişmeler ışı̆̆ında muhasebe eğitiminde yapılabilecek değişiklikler ele alınarak ortaya konacak lisansüstü çalışmalar ile daha verimli bir muhasebe eğitimi sağlanabilir.

$\checkmark$ Uluslararası muhasebe eğitimi standartları ile Türkiye'de verilen muhasebe eğitimi arasındaki ilişki konusunda tezler yazılabilir.

$\checkmark$ Verilen muhasebe eğitimi ile uygulama arasındaki benzerlik ya da farklılıklar incelenerek muhasebe eğitiminde yapılması gereken değişiklikler ele alınabilir.

$\checkmark$ Muhasebe eğitimi alan kişileri istihdam eden işletmeler düzeyinde bir çalışma gerçekleştirilerek oluşan talep ve beklentiler çerçevesinde muhasebe eğitimine yönelik öneriler sunan lisansüstü tezler yazılabilir. Diğer taraftan muhasebe eğitimi alan kişilerin istihdam düzeyi, işe girişte sağladığı katkı ve benzeri konular ele alınabilir.

$\checkmark$ Türkiye Muhasebe Eğitimi Sempozyumlarında ve diğer akademik organizasyonlarda ele alınan muhasebe eğitimi ile teknoloji, kalite, bankacılık, etik ve benzeri konular arasındaki ilişkiyi ele alan lisansüstü çalışmaların sayısı arttırılarak önemli sonuçlar elde edilebilir.

$\checkmark$ Teknolojik gelişmeler (yapay zekâ, arttırılmış gerçeklik, yaygın bilişim, robot teknolojisi, mobil teknolojiler, vb.) ve değişimler çerçevesinde daha dinamik muhasebe eğitimi ve öğretimi için yeni yaklaşımlar incelenerek tez konusu yapılabilir.

$\checkmark \quad$ Küreselleşme faktörü doğrultusunda muhasebe eğitimi ile ilgili akreditasyon ya da uluslararası standartlar lisansüstü çalışmalarda konu edilebilir. Benzer şekilde artan uluslararası öğrenci hareketliliği kapsamında uluslararası öğrenci sayısının artmasına paralel olarak muhasebe eğitimi ile ilgili olarak nasıl bir strateji izlenebileceğine dair öneriler sunan lisansüstü çalışmalar gerçekleştirilebilir.

$\checkmark$ Gelişmiş ve gelişmekte olan ülkelerde verilen muhasebe eğitiminin sistemi ve özellikleri dikkate alınarak ya da karşılaştırmalar ile muhtelif lisansüstü çalışmalar yapılarak önemli çıkarımlarda bulunulabilir.

$\checkmark$ Gelecekte muhasebe eğitimi verecek ve alacak kişilerin sahip olduğu veya olacağ özellikler (kuşak farkından ve diğer nedenlerden kaynakll) dikkate alınarak olması gereken muhasebe eğitimine dair öneriler içeren çalışmalar yapılabilir.

$\checkmark$ Eğitim ve öğretimde ortaya çıkan ters-düz sınıflar, teknoloji destekli esnek öğrenme ve benzeri yenilikler ya da Kahoot, Socrative ve benzeri online araçlar muhasebe eğitimine (ders içeriklerine, ders araçlarına, vb.) uyarlanarak daha verimli sonuçların alınabilmesi adına muhtelif konularda çalışmalar yürütülebilir.

Muhasebe eğitiminde yer alan tüm aktörlerin (ĕgitimi alan ile ĕgitim veren kişi ve kurum, eğitim materyalleri, vb.) performansının objektif bir şekilde değerlendirilmesi ve ortaya çıkan bulgulardan hareketle performansın arttırılmasına yönelik muhasebe eğitimi yapısında gerekli değişiklikler öneren çalışmalar gerçekleştirilebilir. 
$\checkmark$ Muhasebe ile ilgili ulusal ve uluslararası düzenleyici kurum ve kuruluşların muhasebe eğitimine etkisini, muhasebe eğitiminden beklentisini ve taleplerini konu edinen çalışmalar yapılabilir.

Sonuç olarak muhasebe eğitimi ile ilgili yapılan lisansüstü çalışmaların ortaya koyduğu sonuçlar ve getirdiği öneriler ile muhasebe eğitiminde yapılabilecek olası değişimlere öncülük etmesi dolayısıyla taşıdığı önem söz konusu çalışmaların gelecekte de geçmiş dönemlerde olduğu gibi artan bir oranda çalışma alanı olacağını göstermektedir. Ağırlıklı olarak mesleki ve Anadolu liseleri ile meslek yüksekokulları düzeyinde yapılan tezlerde ortaya konan bulgulardan hareketle bu kurumlara yapılan muhtelif iyileştirmelerin veya önerilerin (staj süresi, hukuk dersi, meslek odalarl ve üniversiteler ile işbirliği ve koordinasyon, $v b$.) gelecekte güncel gelişmelere paralel olarak yapılacak farklı konulardaki çalışmalar ile birlikte başta üniversiteler olmak üzere muhasebe eğitiminin verildiği tüm kurum ve kuruluşlarda da değişime (eğitimi alacak yeni kuşakların özelliklerine göre muhasebe eğitiminin verilme şekli, teknolojik gelişime paralel olarak muhasebenin yapılma şekli, kullanulacak olan eğitim materyalleri, uygulamaya yönelik yenilikler, uluslararası işbirlikleri ve entegrasyon, vb.) yol açabileceği öngörülebilmektedir. Bununla birlikte bu konuda çalışma yapacak öğrenci ile danışmanlarının literatürde ve bu çalışmada ortaya çıkan sonuçlardan ve önerilerden hareketle muhasebe eğitiminin geleceğine değer katacak çalışmalar yürütebileceği düşünülmektedir.

\section{KAYNAKLAR}

Alkan, Gönül (2014), “Türkiye'de Muhasebe Alanında Yapılan Lisansüstü Tez Çalışmaları Üzerine Bir Araştırma (1984-2012)”, Muhasebe ve Finansman Dergisi, 61, ss.41-52.

Altınay, Ayşenur Tarakcıŏglu (2016), "Muhasebe Eğitiminin Geleceğine Stratejik Bir Bakış", İnsan ve Toplum Bilimleri Araştırma Dergisi, 5, 7, ss.2144-2150.

Belverd, E. Needles (2014), Modelling Accounting Education içinde R. M. S. Wilson (Ed.), The Routledge Companion to Accounting Education, Routledge-Taylor \& Francis Group, New York.

Burnett, Sharon (2003), “The Future of Accounting Education: A Regional Perspective” , Journal of Education for Business, 78, 3, pp.129-134.

Çelenk, Hakan - Atmaca, Metin - Horasan, Emre (2010), “Marmara Üniversitesi’nde Muhasebe Eğitimi Alan Öğrencilerin Muhasebe Alanına Bakış Açılarının Değerlendirilmesine Yönelik Bir Araştırma”, Öneri Dergisi, 9, 33, ss.159-171.

Çelikdemir, Neşe Çoban (2019), "Türkiye de Muhasebe Standartları Konusunda Yapılan Tezlerin İncelenmesi. İşletme Araştırmaları Dergisi”, 11, 1, ss.325-336.

Drisko, James. W. - Maschi, Tina (2016), Content Analysis, Oxford University Press, Oxford. 
Durgut, Mehmet - Pehlivan, Abdülkadir (2018), "Muhasebe (Finansal Raporlama) Standartlarına Yönelik Türkiye'de Hazırlanan Lisansüstü Tez Çalışmaları Üzerine Bir Araştırma: 1987-2017 Dönemi”, Muhasebe ve Vergi Uygulamaları Dergisi (MUVU), Özel Say1, ss.1-23.

Gücenme, Ümit (2006), “1979-2005 Yılları Arasında Düzenlenen Türkiye Muhasebe Eğitimi Sempozyumları Üzerine Bir Değerlendirme”, Muhasebe ve Finansman Dergisi, 31, ss.33-40.

Güleç, Ömer Faruk - Öztürk, Erkan (2019), "Muhasebe Alanında Türkiye'deki Tezlerle Uluslararas1 Alan Endekslerinde Taranan Dergilerde Yayınlanan Makalelerin Karşılaştırılması", Muhasebe ve Vergi Uygulamaları Dergisi (MUVU), 12, 2, ss.215236.

Güney, Aysel (2019), “Akreditasyon Sürecinde Muhasebe Eğitimi”, Kastamonu Eğitim Dergisi, 27, 2, ss.939-947.

Güngörmüş, Ali Haydar (2016), "Türkiye'de Muhasebe Standartlarına Yönelik Yazılan Yüksek Lisans ve Doktora Tez Çalışmaları Üzerine Bir Araştırma", Pamukkale Üniversitesi Sosyal Bilimler Enstitüsü Dergisi, 25, ss.347-362.

Güvemli, Oktay (2009), "Muhasebe Eğitim ve Uygulamalarını Etkileyen ve Yeni Yüzyılın Başlarını Biçimlendiren Gelişmeler ve Bu Gelişmelerin MUFAD'ın Faaliyetlerini Etkilemesi”, Muhasebe ve Finansman Dergisi, 42, ss.229-232.

Hindmarch, Arthur - Atchison, Miles - Marke, Richard (1977) Accounting: An Introduction, Macmillan Education UK, London.

Kaya, Hatice Pınar (2019), “Türkiye'de Denetim Alanında Yazılmış Olan Doktora Tezlerinin Değerlendirilmesi (1995-2018)”, Karabük Üniversitesi Sosyal Bilimler Enstitüsü Dergisi, 9(2), ss.556-576.

Kaya, İdil (Çeviren) (1999), "Geleceğin Muhasebe Eğitimi: Gelişen Meslek için Hazırlanmak - Amerikan Muhasebe Derneği Muhasebe Eğitiminin Gelecekteki Yapısı, İçeriği ve Kapsamı Kurulu (Özel Rapor)", İstanbul Üniversitesi Siyasal Bilgiler Fakültesi Dergisi, No:20, ss. 61-80.

Kıll1, Mustafa (2016), “Türkiye'deki Üniversitelerde Adli Muhasebe Eğitimi ve Lisansüstü Çalışmalar Üzerine Bir İnceleme", Uluslararası Yönetim İktisat ve İşletme Dergisi, 12 (ICAFR 16 Özel Sayıs1), ss.719-728.

Korukoğlu, Ayşen (1998), "İşletmelerde Muhasebe Eğitimi ve Üniversitelerle İşbirliği", Dokuz Eylül Üniversitesi İktisadi ve İdari Bilimler Fakültesi Dergisi, 13, 11, ss.13-24.

Mueller, G. Gerhard (1994), Global Challenges for Accounting Education içinde Accounting Education for the 21st Century: The Global Challenges, Pergamon, Oxford.

Özdoğan, Seher Turanlı (1978), Muhasebe Öğretim Metodları El Kitabı, Ticaret ve Turizm Yüksek Öğretmen Okulu Yayınları, Ankara. 
Pincus, Karen V. - Stout, David. E. - Sorensen, James. E. - Stocks, Kevin D. - Lawson, Raef A. (2017), "Forces for Change in Higher Education and Implications for the Accounting Academy”, Journal of Accounting Education, 40, pp.1-18.

Şahin, Elif Tuğba - Karaaslanoğlu, Funda (2019), “2013-2018 Y1lları Arasında Türkiye'de Muhasebe Alanında Yapılan Lisansüstü Tezlerin İncelenmesi”, XXXVIII. Türkiye Muhasebe Eğitimi Sempozyumu (Kırk Yılın Muhasebesi ve Yeni Hayallerimiz), İstanbul Üniversitesi İşletme Fakültesi Muhasebe Enstitüsü, Denizli, ss.89-102.

Şengel, Salim (1998), “Almanya'da Muhasebe Eğitimi ve Türkiye İçin Bir Model Önerisi”, Anadolu Üniversitesi İktisadi ve İdari Bilimler Fakültesi Dergisi, 14, 1, ss.245-260.

Şimşek, Hasan - Yıldırım, Ali (2016), Sosyal Bilimlerde Nitel Araştırma Yöntemleri, Seçkin Yayınc1lık, Ankara.

Tekşen, Ömer - Tekin, Muzaffer - Gençtürk, Mehmet (2010), "Muhasebe Eğitiminin Değerlendirilmesi: Mehmet Akif Ersoy Üniversitesi'ne Bağlı Meslek Yüksekokulları Öğrencileri Üzerine Bir Araştırma”, Muhasebe ve Finansman Dergisi, 46, ss.100-112.

Türegün, Nida - Kaya, Can Tansel (2019), “Küreselleşmenin Türkiye’deki Yükseköğretim ve Muhasebe Eğitimi Üzerindeki Etkileri”, Yükseköğretm ve Bilim Dergisi, 9, 2, ss.335341.

Uyar, Güler Ferhan Ünal (2018), “Yükseköğretim Ulusal Tez Merkezi’nde Kayıtlı "Muhasebe Hata ve Hileleri” Konulu Tezlerin Analizi”, Journal of Current Researches on Social Sciences, 8, 4, ss.511-526.

Yaşar, Rukiye Şebnem (2019), "Kalıpların Dışına Çıkmak: Yetkinlik Odaklı Muhasebe Eğitimi”, Muhasebe ve Finansman Dergisi, 81, ss.85-100.

Yeşil, Tolga - Akyüz, Fatma (2018), "Muhasebe Alanındaki Ulusal Doktora Tezlerinin Bibliyometrik Analizi”, Muhasebe Bilim Dünyası Dergisi, 20, ss.440-472.

Yücel, Serkan - Öncü, Mehmet Akid - Kartal, Osman (2015), “Türkiye’de Muhasebe ve Finansal Raporlama Standartları Konularında Yayınlanmış Akademik Çalışmalar (2007-2014 Arası Literatür Taramas1)", Muhasebe ve Finansman Dergisi, 68, ss.3965. 
